\title{
Ucieleśnienie poznania to nie to, co myślisz
}

\author{
Andrew D. Wilson* i Sabrina Golonka \\ Katedra Nauk Społecznych, Psychologicznych i Komunikacyjnych \\ Uniwersytet Metropolitalny w Leeds \\ ${ }^{*}$ a.d.wilson[]leedsmet.ac.uk \\ Przekład: Monika Włudzik i Przemysław Nowakowski
}

(Tekst oryginalny pt. „Embodied cognition is not what you think it is” ukazał się w Frontiers in Psychology, Volume 4, Article 58 ${ }^{6}$ )

Przekład zaakceptowano: czerwiec 2014; opublikowano: lato 2014.

\begin{abstract}
Abstrakt
Najbardziej fascynującą obecnie hipotezą w kognitywistyce jest teoria mówiąca o tym, że poznanie jest ucieleśnione. Tak jak inne dobre pomysły w naukach poznawczych, „ucieleśnienie” może jednocześnie posiadać przynajmniej sześć różnych znaczeń. Najpopularniejsze definicje tego pojęcia opierają się na prostym założeniu, że „stany ciała wpływają na stany umysłu”; implikacje hipotezy o ucieleśnieniu prowadzą jednak do bardziej radykalnych wniosków. Jeśli poznanie dotyczy mózgu, ciała i środowiska, to „stany umysłu” w odcieleśnionej kognitywistyce nie istnieją, więc też nie można ich modyfikować. Wobec tego poznanie jawi się jako rozszerzony system złożony z wielu zasobów, a poważna refleksja nad ucieleśnieniem wymaga nowych metod i nowej teorii. W niniejszym artykule opisujemy cztery główne założenia, na których powinny opierać się programy badawcze zakładające dogłębną analizę implikacji tezy o ucieleśnieniu poznania. Pierwszym krokiem jest analiza zadaniowa opisująca z perspektywy pierwszoosobowej konkretne zadanie, które ma wykonać percypujący i działający podmiot [ang. agent]. Następnie należy określić, jakie zasoby odpowiednie do wykonania zadania dostępne są poznającemu podmiotowi. Pojęcie zasobów obejmuje mózg, ciało i środowisko. Trzecim krokiem jest zdefiniowanie sposobów, w jaki działający podmiot może połączyć dostępne zasoby, tak by stworzyć system zdolny do rozwiązania wyznaczonego zadania. Kolejnym krokiem jest sprawdzenie, czy działania pojęte przez podmiot zostały opisane w punkcie trzecim. Powyższą procedurę przedstawimy szczegółowo, odnosząc się do dwóch wyrazistych przykładów
\end{abstract}

\footnotetext{
${ }^{6}$ Przekład publikowany za zgodą właścicieli praw do tekstu.
} 
(problemu zapolowego ${ }^{7}$ i błędu $\mathrm{AB}^{8}$ ) oraz objaśnimy, jak stosować wspomnianą analizę do złożonej kwestii wykorzystania języka. Poznanie ucieleśnione jest czymś więcej niż nam się wydaje. Mamy też dostęp do narzędzi, które pozwolą nam uświadomić sobie w pełni konsekwencje tego twierdzenia.

Słowa kluczowe: poznanie ucieleśnione; systemy dynamiczne; hipoteza zastąpienia; robotyka; problem zapolowego; błąd AB; język.

\section{Wprowadzenie}

Najbardziej fascynującą obecnie hipotezą w kognitywistyce jest teoria mówiąca o tym, że poznanie jest ucieleśnione. To jedna z tych rzeczy, które zainteresowani laicy wiedzą o kognitywistyce, głównie dzięki popularyzacji wyników badań eksperymentalnych. Wspomniane badania pokazują, (1) jak poznanie może być ukierunkowywane i kształtowane przez stany ciała (np. Eerland i in. 2011) oraz środowiska (Adam i Galinsky 2012), lub (2) jak abstrakcyjne stany poznawcze są zakorzenione w stanach ciała i jak użytkowanie pierwszych wpływa na drugie (np. Lakoff i Johnson 1980, 1999; Miles i in. 2010).

Problem polega na tym, że nie o to chodzi $w$ poznaniu ucieleśnionym. Ucieleśnienie to zaskakująco radykalna hipoteza, która mówi o tym, że mózg nie jest jedynym dostępnym zasobem poznawczym służącym do rozwiązywania problemów. Nasze ciała poprzez zmysłowo zapośredniczone poruszanie się w świecie wykonują większość pracy niezbędnej do osiągnięcia naszych celów, zastępując tym potrzebę złożonych wewnętrznych przedstawień umysłowych. To proste stwierdzenie całkowicie zmienia nasze pojmowanie założeń „poznania”. Ucieleśnienie nie jest po prostu kolejnym czynnikiem wpływającym na odcieleśnione procesy poznawcze.

Wielu badaczy zajmujących się naukami o poznaniu uważa, że powyższa teza wyznacza skrajne punkty na kontinuum ucieleśnienia, i poprzestaje na stwierdzeniu, że różne definicje ucieleśnienia mogą ze sobą współistnieć; być może jest ich trzy (Shapiro 2011) bądź nawet sześć (Wilson 2002). Dlaczego mamy rezygnować z programów badawczych przynoszących rezultaty? Dlaczego $\mathrm{w}$ badaniach nad poznaniem ucieleśnionym nie mielibyśmy skupić się tylko na jednym jego rodzaju i sprawdzać, jak stany ciała mogą wpływać na poznanie lub jak działają systemy poznawcze mózg-ciało-środowisko? Chodzi o to, że pierwszy typ badań nie wykorzystuje w pełni trafnych wniosków płynących z założenia, że poznanie to więcej niż działanie samego mózgu. Taka

\footnotetext{
${ }^{7}$ Zapolowy (ang. outfielder) to zawodnik obrony grający na najbardziej wysuniętej pozycji (zapolu) w baseballu. http://www.baseball.pl/o-grach/zasady.html, DOA 06/06/2014 [przyp. tłum.].

${ }^{8}$ Wg klasycznej teorii poznania Piageta błąd popełniany przez dzieci do 12 miesiąca życia polegający na poszukiwaniu uprzednio przemieszczonych przedmiotów w ich pierwotnej lokalizacji (zob. Damon i in. 2006: 742-746 [przyp. tłum.].
} 
zmiana akcentu w kognitywistyce prowadziłaby nieuchronnie do przeniesienia nacisku z ulepszania podstawowych zdolności na zrozumienie, jak nasze zachowanie wyłania się z ciągłych wzajemnych zależności między zasobami służącymi do rozwiązywania poszczególnych zadań zlokalizowanych w mózgu, ciele, środowisku i połączonych przez nasze systemy percepcyjne.

Omówmy strukturę artykułu. Po wyłożeniu standardowych sposobów wyjaśniania zachowań w psychologii poznawczej krótko odniesiemy się do niektórych interesujących kierunków badań empirycznych w robotyce i nad poznaniem u zwierząt, badań potwierdzających mocną hipotezę zastąpienia w poznaniu ucieleśnionym (Shapiro 2011). Następnie przedstawimy zalecaną strategię badań opartą na tych pracach. Opiszemy, jak należy używać analizy zadaniowej do zidentyfikowania wymogów poznawczych danego zadania oraz dostępnych zasobów (mózgowych, cielesnych i środowiskowych) do ich wypełnienia. Według autorów niniejszej analizy zadaniem empirycznego programu badawczego jest określenie, które z dostępnych zasobów są wykorzystywane przez organizm, jak zostały one połączone, skoordynowane i poddane kontroli, tworząc rodzaj inteligentnego, zorientowanego zadaniowo urządzenia dostosowanego do rozwiązywania danego problemu (Runeson 1977; Bingham 1988). Przedstawimy szczegółowo dwa klasyczne przykłady: problem zapolowego (np. McBeath i in. 1995) i błąd $A B$ (np. Thelen i in. 2001). Następnie zestawimy podejście zadaniowe $\mathrm{z}$ wybranymi badaniami nad poznaniem ucieleśnionym typowymi dla psychologii poznawczej, by sprawdzić, na ile trudno jest za pomocą badań tego rodzaju przeanalizować rolę ciała lub środowiska w poznaniu, również tę zidentyfikowaną w badaniu. Artykuł kończymy wnioskami dotyczącymi stosowania podejścia zadaniowego do jednego z najtrudniejszych zagadnień w naukach o poznaniu: praktyki językowej. Język jest tradycyjnie uważany za wielką niewiadomą radykalnej koncepcji ucieleśnienia, ale przy odrobinie wysiłku, jak zamierzamy wykazać w zakończeniu, prawdziwie ucieleśniona analiza języka jest możliwa.

\section{Standardowe sposoby wyjaśniania zachowania w kognitywistyce}

Psychologowie zajmujący się poznaniem wcześnie doszli do wniosku, że nasze zachowanie zależne jest od wewnętrznych [stanów] organizmu. Za klasyczny przykład takiego podejścia można uznać krytykę „zachowań werbalnych” (Skinner 1957) przeprowadzoną przez Chomsky’ego, który uważał, że nie można wyjaśnić umiejętności nauki i korzystania z języka bez odniesienia się do struktur umysłowych (w tym przypadku - do wrodzonych zdolności językowych). Można zatem ogólnie stwierdzić, że psychologowie poznawczy, opisując proces mediacji między organizmem a środowiskiem, często posługują się pojęciem reprezentacji umysłowych.

Podczas gdy wspomniane teorie zyskiwały rozgłos, wyniki badań nad percepcją potwierdziły założenie, że nasz zmysłowy dostęp do świata jest znacznie 
ograniczony (zob. Marr 1982; Rock 1985 recenzje). Tym samym reprezentacje umysłowe służą rozwiązaniu następującego problemu: mózg jest odcięty od świata zewnętrznego, poznanie zmysłowe zapewnia jedynie zubożony, probabilistyczny dostęp do świata, a jednak to właśnie mózg jest odpowiedzialny za kierowanie szybkimi, funkcjonalnymi i odpowiednimi zachowaniami $\mathrm{w}$ dynamicznym środowisku fizycznym i społecznym. Percepcja zmysłowa stanowi niepełną formę poznania, więc nie można jej uznać za dominującą $\mathrm{w}$ procesach poznawczych. Podobnie środowisko, do którego zyskujemy dostęp tylko na drodze percepcji zmysłowej, nie może być traktowane jako dominujące. Zatem mózg powinien odgrywać rolę składnicy wiedzy i umiejętności, do których można uzyskać szybki dostęp, odpowiednio je sparametryzować i zastosować, opierając się na możliwe prawdopodobnej interpretacji zgromadzonych informacji pochodzących z percepcji zmysłowej i wewnętrznych struktur umysłowych. Powyższy opis wskazuje na to, że treść wewnętrznych reprezentacji umysłowych jest najważniejszym czynnikiem kształtującym strukturę ludzkich zachowań. Nauki o poznaniu powinny więc przede wszystkim zająć się identyfikowaniem tych treści oraz sposobów dostępu do nich i ich wykorzystania (więcej na ten temat w: Dietrich i Markman 2003).

Postęp w badaniach nad związkiem percepcji i działania, a w szczególności prace Gibsona o percepcji bezpośredniej (Gibson 1966, 1979) redefiniują naturę problemów, z którymi musi zmierzyć się organizm. Percepcja nie jest całkowicie błędna, posiadamy wysokiej jakości, bezpośredni dostęp do świata, tym samym percepcja (i zarazem środowisko) jest ważnym zasobem poznawczym, a nie problemem, z którym trzeba się zmierzyć, doskonaląc procesy percepcji zmysłowej. Koncepcja poznania ucieleśnionego (w każdej formie) uznaje znaczenie percepcji, działania i środowiska w procesach poznawczych.

Przyjęcie powyższych założeń prowadzi do radykalnych wniosków: jeśli sprzężenia działania i percepcji oraz zasoby informacyjne znajdujące się w mózgu, ciele i środowisku są ważnymi składnikami procesu poznania, to za zbędne można uznać przedmioty i procesy zdefiniowane przez standardową psychologię poznawczą (pojęcia, umiejętność tworzenia reprezentacji wewnętrznych, wiedzę), które należy zastąpić innymi przedmiotami i procesami (najczęściej są to sprzężenia działania i percepcji tworzące nieliniowe systemy dynamiczne, np. van Gelder 1995). Tak skrótowo można by opisać wersję koncepcji ucieleśnienia nazwaną przez Shapiro (2011) hipoteza zastapienia. Uważamy, że przyjęcie tej hipotezy jest nieunikniona konsekwencją uznania ról odgrywanych przez ciało $i$ środowisko $w$ procesach poznawczych. Jeśli uznamy hipotezę zastąpienia za obowiązującą, to okaże się, że badania przyjmujące standardowe założenia psychologii poznawczej i zajmujące się wpływem stanu ciała na procesy poznawcze mijają się z celem. Aby zasłużyć na swoje miano, badania nad procesami poznawczymi powinny, jak sądzimy, zdecydowanie różnić się od podejścia standardowego. 


\section{Poznanie ucieleśnione: cztery kluczowe pytania}

Pytanie, dlaczego dane zachowanie ma taka, a nie inna formę, to zasadnicze pytanie psychologii. Standardowa psychologia poznawcza wyjaśnia tę kwestię w sposób następujący: forma zachowania odzwierciedla zawartość i działanie wewnętrznego algorytmu (stosowanego $\mathrm{w}$ formie reprezentacji umysłowych) służącego uzyskaniu wymaganego zachowania (np. Fodor 1975, 2008). W pracach omawianych w dalszych częściach artykułu złożone wewnętrzne struktury kontrolne zastąpiono starannie zbudowanymi ciałami, percepcyjnie dostosowanymi do otaczającego je środowiska (nie ulega wątpliwości, że rozwiązania sugerowane $\mathrm{w}$ koncepcji poznania ucieleśnionego będą również sporadycznie odnosić się do mechanizmów sterowania wewnętrznego. Co jednak istotne, wewnętrzne struktury sterujące biorą udział w działaniach rozproszonych i zmysłowo sprzężonych systemów, które skutkują wykonywaniem określonych czynności na bieżąco, w czasie rzeczywistym i danym kontekście. Z tego powodu w koncepcji poznania ucieleśnionego nie ma miejsca na jednoznaczne reprezentowanie zachowań lub wiedzy).

Naszym zdaniem realizacja powyższych założeń w programach badawczych zajmujących się procesami poznawczymi wymaga zmierzenia się z czterema podstawowymi pytaniami:

1. Jakie zadanie należy wykonać? Ucieleśniona percepcja pozwala na rozwiązanie konkretnych zadań praktycznych, nie problemów ogólnych, więc analiza sposobu, w jaki dany organizm wywołuje określone zachowanie, oznacza dokładne opisanie problemu, który ten organizm w danym czasie rozwiązuje. Badanie wybranego zadania wiąże się z możliwością zdefiniowania sprytnych rozwiązań (Runeson 1977). Organizmy stosujące owe sprytne rozwiązania radzą sobie z danym problemem, posługując się heurystyką stałych właściwości przypisanych do konkretnych zadań, nie używają natomiast uniwersalnych pamięciowych aparatów umożliwiających zastosowanie algorytmów w celu rozwiązania zadania. W przypadku często powtarzających się czynności stosowanie sprytnych rozwiązań staje się bardziej efektywne, stabilne i ekonomiczne niż rozwiązania pamięciowe (np. Zhu i Bingham 2008, 2010).

2. Do jakich zasobów ma dostęp organizm wykonujący dane zadanie? Koncepcja poznania ucieleśnionego zakłada, że istnieją zasoby - w liczbie mnogiej - dostępne organizmowi. Do takich zasobów należy mózg, ale również ciało, środowisko oraz związki między nimi (na przykład ruch ciała w środowisku). Istotnym elementem analizy zadaniowej powinna być wyczerpująca lista dostępnych zasobów przydatnych do wykonania określonej czynności, zaczynając od tych dostępnych na drodze percepcji i działania, a kończąc na hipotezach dotyczących bardziej złożonych zasobów poznawczych wykorzystywanych po wyczerpaniu zasobów pierwszego rodzaju. Sporządzenie wyczerpującej listy jest możliwe, jeśli można wybrane zadanie opisać pod względem struktury. Poszczególne zadania są odróżniane od siebie na podstawie ich 
wewnętrznej dynamiki (np. Bingham 1995), dlatego też coraz częściej formalizuje się opis zadania za pomocą narzędzi teorii układów dynamicznych (np. Fajen i Warren 2003; Bingham 2004a,b; Schöner i Thelen 2006).

3. Jak można skonfigurować dostępne zasoby, by rozwiązać dane zadanie? Rozwiązanie konkretnego zadania wymaga stworzenia inteligentnego aparatu przeznaczonego do użytku w danej sytuacji (Bingham 1988). Innymi słowy oznacza zbudowanie systemu z potrzebnych zasobów. Taki system powinien pozwolić na rozwiązanie wspomnianego zadania w miarę wytwarzania określonych zachowań. Zasoby są rozproszone, znajdują się w mózgu, ciele i środowisku. Ponieważ uzyskujemy dostęp do informacji na temat ciała i środowiska na drodze percepcji, analiza ucieleśnienia powinna zawierać szczegółowy opis danych zmysłowych wykorzystanych do połączenia zróżnicowanych zasobów (Golonka i Wilson 2012).

4. Czy organizm rzeczywiście konfiguruje i wykorzystuje konkretne zasoby? Kwestią empiryczną pozostaje pytanie, czy układ dynamiczny hipotetycznie przedstawiony w punkcie trzecim można uznać za dokładny opis systemu skonfigurowanego przez organizm, by rozwiązać określone zadanie. Podstawowym narzędziem służącym do określenia tożsamości układu dynamicznego jest eksperymentalne wprowadzenie zakłóceń. Systemy odpowiadają na zmiany $\mathrm{w}$ dostępności zasobów w sposób, który odzwierciedla rolę odgrywaną przez dany zasób w układzie, co pozwala szybko mapować budowę i organizację danego systemu (np. Kay i in. 1987, 1991; Wilson i Bingham 2008).

Zadaniem następnych części artykułu jest przedstawienie zastosowania nowej praktyki badawczej. Na początku przyjrzymy się pewnym prostszym przypadkom, które pomogą $\mathrm{w}$ wyjaśnieniu i rozwiązaniu niektórych $\mathrm{z}$ naszych czterech podstawowych kwestii; później przejdziemy do omówienia dwóch przypadków zachowań ludzkich i pokażemy, w jaki sposób, opierając się na sformułowanych przez nas czterech pytaniach, można stworzyć spójny program badawczy.

\section{Ucieleśnienie w działaniu}

\section{Ucieleśnienie w działaniu I: Roboty}

Robotyka należy do dziedzin najbardziej owocnych, jeżeli chodzi o wykazywanie zasadności hipotezy zastąpienia. Roboty zbudowane według zasad zdefiniowanych $\mathrm{w}$ kategoriach ucieleśnienia mogą wykazywać zaskakująco skomplikowane zachowania, pokazując w ten sposób, jak daleko można dojść bez posługiwania się reprezentacjami umysłowymi. Gdy własnoręcznie zbuduje się coś od początku, wówczas dokładnie wiadomo, co wchodzi (lub nie) w skład systemów sterujących. W ten sposób można ograniczyć i wyliczyć liczbę potencjalnych wyjaśnień danego zachowania, co pozwala szczegółowo odpowiedzieć na pytania nr 2 i 3. 
„Szwajcarskie” roboty

Wczesnym przykładem zastosowania hipotezy poznania ucieleśnionego w robotyce jest Didabot skonstruowany przez Maris i te Boekhorst (1996). Didabot został wyposażony w wykrywacze podczerwieni na całej powierzchni i uproszczoną strukturę kontrolną: zbudowaną zgodnie z zasadą „odwróć się od wykrytej przeszkody". W trakcie opisanego w artykule eksperymentu wykrywacz podczerwieni na przedniej części robota został wyłączony - robot nie mógł „zobaczyć” przeszkód znajdujących się bezpośrednio przed nim, ale mógł „zobaczyć”, co znajduje się po obu stronach i z tyłu. Jeśli uderzył w przeszkodę (biały klocek) przodem, przemieszczał się dalej i przesuwał klocek do przodu, aż do momentu, gdy odwrócił się, by uniknąć kolejnej przeszkody (następny klocek lub ściana). Wtedy pierwszy klocek zostawał na miejscu i w rezultacie powstawała sieć (pod warunkiem, że pracował więcej niż jeden robot) „uporządkowanych” stosów początkowo chaotycznie rozrzuconych klocków. Takie zachowanie porządkujące nie zostało wpisane w struktury kontrolne robotów, ale pojawiło się w czasie rzeczywistym na skutek związku między przyjętą zasadą, środowiskiem (rozmiar i liczba przeszkód, obecność lub nieobecność innych robotów) oraz mechanizmem robotów (pracujące czujniki muszą być wystarczająco od siebie oddalone, by umożliwić robotowi pominięcie klocka, w przeciwnym razie robot będzie skutecznie omijał wszystkie klocki). Warto zaznaczyć, że roboty tak naprawdę nie porządkują klocków celowo, po prostu starają się unikać przeszkód, a ich błędy w danym rozszerzonym i ucieleśnionym kontekście prowadzą do uzyskania stałego rezultatu przypominającego porządkowanie (por. Pfeifer i Scheier 1999; Pfeifer i Bongard 2007 - zawiera więcej informacji na temat robotyki tego typu). Zrozumienie zasobów dostępnych robotom i sposobów ich wykorzystania przez roboty pozwoliło na stwierdzenie, że roboty w rzeczywistości niczego nie porządkowały.

\section{Lokomocja i dynamika pasywna}

Dlaczego chodzenie posiada taką formę, a nie inną? Według jednego z możliwych wyjaśnień posiadamy wewnętrzny algorytm, który kontroluje rytm i wielkość naszych kroków. Inne umotywowanie formy chodzenia zakłada, że jest ono zależne od budowy ciała i związku jego anatomii ze środowiskami, w których się przemieszczamy.

Zasadniczą kwestią, którą należy rozważyć, zastanawiając się nad zasobami dostępnymi podczas rozwiązywania tego zadania, jest budowa organizmu. Ludzie nie chodzą jak lwy, ponieważ nasze ciała nie są tak zbudowane jak ciała lwów. Właściwości naszych ciał określane są mianem dynamiki pasywnej (McGeer 1990). Jak rozmieszczone są poszczególne elementy? Jak są ze sobą połączone? Czy połączenia między nimi są elastyczne? Prace z zakresu robo- 
tyki dotyczące mechaniki chodzenia pokazują, że refleksja nad dynamiką pasywną stanowi bardzo ważną część wyjaśnienia formy chodzenia. Na przykład roboty pozbawione silników lub pokładowych algorytmów sterujących mogą odtwarzać mechanikę rytmu ludzkich kroków i poziomów efektywności po prawidłowym skonfigurowaniu (np. Collins i in. 2005) ${ }^{9}$. W badaniach prowadzonych w Instytucie Technologii w Massachusetts do systemów tego rodzaju dodano proste algorytmy sterujące, umożliwiając robotom utrzymanie postawy i właściwego napędu. Ten sam algorytm doprowadził do powstania różnorodnych zachowań lokomocyjnych, zależnych od budowy sterowanego robota (np. Raibert 1986) ${ }^{10}$. Żaden ze stworzonych systemów nie zawierał reprezentacji ostatecznej formy lokomocji. Forma zostaje nadana ruchom robotów w czasie rzeczywistym dzięki interakcjom zachodzącym między ich dynamiką pasywną a środowiskiem podczas poruszania się. Przykład robotów pokazuje, w jaki sposób organizmy żywe mogą wykorzystywać rozproszone zasoby podczas wykonywania zadania i zastępować nimi złożone wewnętrzne struktury kontroli.

\section{Mechaniczne świerszcze}

Fascynujący przykład ucieleśnienia ze świata natury został odtworzony laboratoryjnie w formie robota (więcej na ten temat w: Barrett 2011). Świerszcze płci żeńskiej muszą znaleźć świerszcze męskie, by doszło do prokreacji. Żeńskie świerszcze chętniej rozmnażają się z samcami, które głośno cykają. Jakimi zasobami posługują się, by rozwiązać to zadanie? Płeć żeńska posiada parę połączonych ze sobą bębenków, po jednym na każdej z przednich nóg. Dźwięki dobiegające $z$ boku aktywują bębenek po danej stronie i za pomocą przewodu dobiegają do bębenka po przeciwnej stronie ciała. Sygnały są odbierane jako rozbieżne, jeśli dźwięk dobiega z boku, co wpływa na częstotliwość odpowiedzi bębenka po danej stronie ciała. Rozmieszczenie narządów słuchu na ciele świerszcza jest kierunkowe, dzięki czemu świerszcze żeńskie mogą określić, z której strony dobiega dźwięk, ale nie wyjaśnia to, jak wykorzystują one tę informację, by przemieszczać się w kierunku źródła dźwięku lub dostroić się do świerszczy własnego gatunku. Bębenki świerszczy połączone są z niewielką liczbą interneuronów kontrolujących obroty ciała. Żeńskie świerszcze zawsze odwracają się w kierunku wyznaczonym przez najaktywniejsze komórki nerwowe. Interneurony danego gatunku świerszcza reagują w podobnych okolicznościach, dlatego też mechanizm odbioru dźwięku wykazuje zwiększoną aktywność w przypadku dźwięków o określonej częstotliwości.

\footnotetext{
${ }^{9}$ Aby zapoznać się z nagraniami wideo oraz innymi szczegółami dotyczącymi tych robotów, zob. http://ruina.tam.cornell.edu/research/

${ }^{10}$ Aby zapoznać się z nagraniami wideo oraz innymi szczegółami, zob. http://www.ai.mit. edu/projects/leglab/
} 
W wyniku tego cykanie męskich świerszczy zostaje dostrojone do danej częstotliwości, toteż bez dokładnych obliczeń i porównań można stwierdzić, że żeński świerszcz odnajduje grającego najgłośniej świerszcza płci przeciwnej. Analiza zasobów potrzebnych do wykonania zadania pokazuje, że świerszcz rozwiązuje ten problem za pomocą narządów ciała (położenie bębenków, połączenia interneuronalne) oraz życia w szczególnym środowisku (w którym świerszcze płci męskiej wydają dźwięki o określonej częstotliwości).

Webb $(1995,1996)$ zbudował roboty, które potrafią wykonywać wyłącznie te proste czynności. Robotom Webba udało się odtworzyć mechanizm znajdowania partnera stosowany przez samice świerszcza. Roboty nie posiadają informacji na temat dźwięków granych przez świerszcze płci męskiej, ale po prostu postrzegają, działają i użytkują specjalnie zaprojektowane ciała. Można jasno stwierdzić, że roboty nie posługują się zasadą „wyboru najgłośniej grającego świerszcza”, lecz znajdują go, ponieważ taki jest wynik zastosowania ucieleśnionej strategii działania w kontekście wielu męskich świerszczy grających jednocześnie, uruchomionej przez (jak dowodzi eksperyment) częstotliwość dźwięków granych przez świerszcza. Sukces tego eksperymentu zależy od dokładnego przeanalizowania zadania, określenia dostępnych zasobów oraz sposobu, w jaki zostaną one wykorzystane przez działający podmiot (pytania 1-3 opisanie powyżej).

\section{Streszczenie}

Przedstawiona praca z zakresu robotyki oraz inne podobne do niej opracowania (np. Brooks 1999; Pfeifer i Scheier 1999; Beer 2003; Pfeifer i Bongard 2007) wskazują na to, że spora część zachowań złożonych (od porządkowania czy lokomocji po poszukiwanie partnerów) może się wykształcić wskutek umieszczenia ciała odpowiedniego typu w konkretnym kontekście środowiskowym, bez jasno wyrażonego przedstawienia danego zachowania w systemie. Tego rodzaju badania potwierdzają, że ucieleśnienie i usytuowanie robota w środowisku może zastapić wewnętrzne algorytmy, prowadząc do wytworzenia stałych zachowań funkcjonalnych.

\section{Ucieleśnienie w działaniu II: Zwierzęta}

Badania nad robotami dostarczają ważnych argumentów wspierających hipotezę zastąpienia. Kolejnym ważnym krokiem jest ustalenie, czy organizmy żywe mogą korzystać z podobnych rozwiązań ucieleśnionych (pytanie 4), czy też raczej posługują się innymi, bardziej obliczeniowymi strategiami działania. 


\section{Znów świerszcze}

Roboty-świerszcze Webba stosują prostą strategię percepcji-działania, dokonując wyboru odpowiedniego partnera. Na podstawie przytoczonej pracy można postawić hipotezę, że samice świerszcza wykorzystują pierwsze dźwięki wydawane przez świerszcze płci męskiej do poszukiwań, nie słuchając całej melodii i nie „wybierając” najlepszego partnera. Obserwacje prowadzone na prawdziwych świerszczach sugerują, że żeńskie świerszcze zaczynają się poruszać, zanim byłyby w stanie wysłuchać całej melodii granej przez samca, tym samym wspierając ucieleśnioną hipotezę „pierwszego dźwięku” (Hedwig i Webb 2005; zob. również ogólny zarys zagadnienia w: Barrett 2011).

\section{Rojenie się, życie w stadzie i polowania}

Wiele zwierząt wykazuje zdolność do wykonywania skoordynowanych czynności w dużych grupach jednego gatunku. Tworzenie się dużych grup (rojów lub stad) stanowi ważny sposób obrony przed drapieżnikami. Życie w grupie wymaga nieustannej współpracy między wieloma osobnikami. Jednak takim przystosowaniem do wspólnego działania nie da się sterować centralnie, nie może też być mowy o celowej próbie utrzymania roju. Wspólne działania osobników pojawiają się i funkcjonują dzięki zasadom bezpośredniego sprzęgnięcia percepcji i działania w odpowiednim kontekście. Tworzenie się ptasich stad można przekonująco wyjaśnić jako sprzężenie jednostek ograniczone trzema zasadami (Reynolds 1987): oddzielenia (nie tłocz się przy innych), równego rozstawienia (leć w uśrednionym kierunku wyznaczonym przez innych) i spójności (leć w kierunku średniej pozycji innych). Zasada spójności rządzi się asymetriami wynikającymi z perceptualnych ograniczeń ptaków, średnia pozycja znajduje się w środku masy tylko najbliższych 5-10 ptaków, co sprawia, że stado leci po skośnej linii (takie jest pole widzenia ptaków; Ballerini i in. 2007). Owcze stada zachowują się w podobny sposób. Gdy zbliża się do nich drapieżnik, owce kierują się do geometrycznego środka stada, stosując strategię „samolubnego stada”, mimo że żadnej z owiec nie można postrzegać jako „samolubnej” sensu stricte (Hamilton 1971; King i in. 2012).

Bardziej skomplikowanym przykładem skoordynowanej aktywności społecznej są wilki polujące w watasze. Jednak wzorzec ich zachowań można opisać za pomocą dwóch prostych zasad: (1) poruszaj się w kierunku ofiary aż do zbliżenia na minimalną bezpieczną odległość, a następnie (2) odsuń się od innych wilków również zbliżających się do ofiary (Muro i in. 2011). W tym przypadku nie jest potrzebny przywódca stada, nie ma też potrzeby wydawania instrukcji. Sposób polowania watahy powstaje na skutek prostego zastosowania sprzężenia percepcji-działania przez każdego z polujących osobników w określonym kontekście. 
W motyw polowania wpisuje się również praca Barrett (2011), w której zostały opisane „nieprawdopodobne zdolności skaczących pająków z rodzaju Portia ${ }^{11}$. Pająk Portia potrafi dokonać zdumiewających wyczynów, takich jak łudzące naśladowanie innych gatunków, celowe rozpraszanie uwagi ofiar, poruszanie się okrężną trasą, by zaskoczyć ofiarę. Ostatnia z wymienionych czynności naprawdę jest godna uwagi, ponieważ zakłada, że pająk Portia musi przez dłuższy czas działać bez bezpośredniego zmysłowego kontaktu z ofiarą. Taka umiejętność zdaje się wymagać umiejętności planowania trasy (Heil 1936; Barrett 2011). Jak zauważa Barrett, powyższa hipoteza początkowo była uważana za prawdopodobną, ponieważ pająk Portia przeszukuje swoje środowisko, zanim zacznie poruszać się okrężną trasą. Pająk zatrzymuje się w miejscu i kołysze się z boku na bok, zdając się oceniać dostępne trasy i wybierać tą właściwą. W rzeczywistości jednak czynność przeszukiwania w połączeniu z budową oczu pająka tworzy formę ucieleśnionej strategii, która umożliwia pająkom tego rodzaju wyznaczenie dostępnych tras na podstawie danych zmysłowych (np. Tarsitano i Jackson, 1997; Tarsitano i Andrew, 1999). Pająk Portia obserwuje, a nie planuje.

\section{Streszczenie}

Świat zwierząt jest cennym źródłem przykładów dla kognitywistyki, ponieważ naukowcy badający faunę są mniej skłonni do przypisywania określonym czynnościom złożonych wewnętrznych przedstawień (skłonność ta jest słabsza, ale oczywiście taka pokusa pozostaje - Kennedy 1992; Barrett 2011). Kiedy jednak przychylimy się do tezy, że ucieleśnione i usytuowane sprzężenia percepcji i działania mogą doprowadzić do wytworzenia złożonych zachowań adaptacyjnych u zwierząt, wówczas trudno zaprzeczyć, że również w przypadku ludzi mamy do czynienia z rozwiązaniami tego rodzaju. Przyjęcie przeciwnego stanowiska byłoby równoznaczne z podważeniem ewolucyjnej ciągłości między ludźmi a resztą królestwa zwierząt.

\section{Ucieleśnienie w działaniu III: ludzie}

Przyjrzymy się teraz szczegółowo dwóm doskonałym przykładom zastosowania hipotezy zastąpienia $\mathrm{w}$ zakresie form poznania ucieleśnionego w psychologii. Te przykłady to problem zapolowego i bład $A B$ (zob. Clark 1999; Smith i Gasser 2005 - inne wykorzystanie tych przykładów). Są one przydatne, ponieważ (a) dają odpowiedź na wszystkie cztery podstawowe pytania

\footnotetext{
${ }^{11}$ Łacińska nazwa gatunku pająka skaczącego z rodziny skakunowatych, żywiącego się innymi pająkami. Posiada zdolność uczenia się i rozwiązywania problemów (zob. Jackson i Wilcox 2002: 17-34) [przyp. tłum.].
} 
promujące dobrą praktykę badawczą $\mathrm{w}$ badaniach nad ucieleśnieniem, (b) oba przykłady można wyjaśnić za pomocą standardowego podejścia w psychologii poznawczej; po licznych badaniach wyjaśnienia tego typu zostały $\mathrm{z}$ powodzeniem zastąpione przez hipotezy 0 ucieleśnieniu zaprezentowane $\mathrm{w}$ niniejszym artykule. Kolejne rozdziały rozpoczniemy od standardowego wyjaśnienia problemu zapolowego i błędu AB w psychologii poznawczej. Następnie cofniemy się i przeanalizujemy każde $\mathrm{z}$ tych zadań z perspektywy poznania ucieleśnionego, zadając cztery kluczowe pytania:

1. Jakie zadanie ma zostać rozwiązane?

2. Do jakich zasobów ma dostęp organizm rozwiązujący dane zadanie?

3. Jak można połączyć dostępne zasoby, rozwiązując dane zadanie?

4. Czy organizm faktycznie łączy i używa tych zasobów?

\section{Ucieleśnienie w działaniu III.I: Problem zapolowego}

Jak zapolowy łapie nadlatującą piłkę? Istnieje wiele czynników, które sprawiają, że zadanie to jest trudne; zapolowy znajduje się daleko od pałkarza, piłka pod względem optycznym jest bardzo mała i taka pozostanie aż do momentu, gdy znajdzie się bardzo blisko zapolowego, który będzie musiał przemieścić się ze swojej początkowej pozycji do miejsca, w którym niebawem wyląduje piłka, aby móc ją złapać.

\section{Rozwiazanie standardowe}

Wstępna hipoteza jest następująca: łapiemy nadlatujące piłki, przewidując ich przyszłe położenie na podstawie fizycznych właściwości ich lotu. Odbita piłka porusza się po krzywej ruchu pocisku; fizyka balistycznego lotu tego rodzaju jest względnie prosta. Dla przedmiotu o określonym rozmiarze i masie podstawowe zmienne określające lot to początkowy kierunek, prędkość oraz kąt lotu (nie licząc dodatkowych ograniczeń, takich jak ciąg, gęstość powietrza, grawitacja). Saxberg (1987 a,b) sugeruje, że zapolowy postrzega te wstępne parametry i używa ich jako danych w wewnętrznej symulacji (reprezentacji) lotu pocisku. Reprezentacje te umożliwiają zapolowemu przewidzenie przyszłego położenia piłki (prognozowanie trajektorii lotu). Przewidziawszy to położenie, zapolowy przemiesza się $\mathrm{w}$ miejsce, gdzie spadnie piłka, i tam czeka.

\section{Rozwiązanie ucieleśnione}

Rozwiązanie Saxberga (1987a,b) zakłada, że czynność łapania piłki jest podobna do rozwiązywania problemu fizycznego w oparciu o pewne ograniczone zasoby (warunki początkowe lotu piłki) i określoną wewnętrzną symulację. 
Natomiast $\mathrm{w}$ ramach podejścia ucieleśnionego kwestionuje się takie przedstawienie problemu i zadaje pytanie: ,jakie $s q$ owe zasoby dostępne przy wykonywaniu zadania i jak mogą one pomóc komuś złapać piłkę?”

\section{Jakie zadanie trzeba wykonać?}

Polowy znajduje się poza boiskiem bejsbolowym, około 250 stóp od bazy domowej. Pałkarz odbija piłkę (ruch po parabolicznej trajektorii), a polowy musi przemieścić się z miejsca, w którym się znajduje, do miejsca, w którym znajdzie się piłka, kiedy uderzy w ziemię (starając się złapać piłkę, zanim spadnie). Zadaniem polowego jest więc wykonanie takich ruchów, by dotrzeć na właściwe miejsce o właściwym czasie i złapać lecaca piłkę. Czasami polowi znajdują się $\mathrm{w}$ linii prostej z lotem piłki, jednak ogólny problem, jaki trzeba tutaj rozwiązać, to wymóg, by polowy, stojąc z boku, zdążył złapać piłkę.

\section{Jakie zasoby są dostępne?}

Na początku należy zauważyć, że biorąc pod uwagę odległości na boisku bejsbolowym, optyczna projekcja lotu piłki bejsbolowej jest niewielka. Próby rozstrzygnięcia, gdzie i jak daleko znajduje się piłka, z wykorzystaniem wzrokowej projekcji rozmiaru w większości przypadków okażą się błędne (o ile w ogóle są możliwe; Cutting i Vishton 1995). Błędy te będą się powtarzać w każdej symulacji i sprawią, że rozwiązania oparte na obliczeniowych symulacjach lotu pocisku okażą się niestabilne. Co oznacza, że rozwiązania uwarunkowane symulacjami prawdopodobnie nie są zasobami wykorzystywanymi podczas rozwiązywania danego problemu (dowody sugerują, że nie ma takiej możliwości; Shaffer i McBeath 2005). A więc jakie inne zasoby są tutaj dostępne?

Aby określić pełen zakres dostępnych zasobów, musimy zrozumieć fizyczne własności lotu piłki. Składowe tego lotu pojawiają się w określonym czasie i różnią się od siebie dynamika (która charakteryzuje zarówno zmiany systemu w czasie, jak i siły, które powodują te zmiany; Bingham 1995). W omawianym przykładzie właściwy punkt odniesienia stanowi dynamika lotu pocisku. Podczas tego lotu wytwarzana jest informacja kinematyczna, którą obserwator może wykryć i wykorzystać. Opis kinematyczny zawiera wyłącznie zmiany w układzie dynamicznym w czasie, bez odniesienia do sił, które je spowodowały. Systemy percepcyjne mogą jedynie wykrywać wzorce kinematyczne, podczas gdy obserwator chce poznać dynamikę zdarzenia, mamy tu zatem do czynienia z wąskim gardłem percepcji (Bingham 1988). Jednak kinematyka może określać dynamikę leżącą u jej podstaw (Runeson i Frykholm 1983), a wykrycie określających ją wzorców kinematycznych jest równoznaczne z postrzeganiem owej bazowej dynamiki (rozwiązując problem wąskiego gar- 
dła i umożliwiając bezpośrednią percepcję, jak to sugerował Gibson 1966, 1979). Z tego powodu informacja, którą zapolowy może wykorzystać, by skierować swoje działania ku przyszłej pozycji piłki, musi być kinematyczna i charakterystyczna dla jej przyszłej pozycji.

Uderzenie pałkarza warunkuje początkową trajektorię piłki (kierunek, prędkość i kąt lotu), po czym lot przebiega zgodnie z dynamiką lotu pocisku. Dany układ dynamiczny wytwarza ruch zgodny z trajektorią paraboliczną. Kształt tego lotu jest następujący: początkowo piłka wznosi się, następnie zwalnia, aż osiągnie wysokość maksymalną, kiedy jej prędkość osiągnie punkt zerowy, zaczyna przyśpieszać i opada po drugiej stronie paraboli. Ruch ten stanowi informację kinematyczną dostępną obserwatorowi.

Polowy dysponuje również własnymi zasobami: zdolnością do wykrywania informacji kinematycznej oraz (co bardziej użyteczne) przemieszczania się po boisku z różnymi prędkościami po wszystkich dostępnych trajektoriach.

Jak można wykorzystać dostępne zasoby, aby rozwiazać to zadanie?

Jak informacja percepcyjna określająca dynamikę lotu piłki może zostać wykorzystana w połączeniu ze zdolnością polowego do postrzegania kinematyki i przemieszczania się? Paraboliczny lot piłki stwarza możliwość dwóch podstawowych rozstrzygnięć. Każda ze strategii wymaga, by zapolowy poruszał się w szczególny sposób, tak by zrównoważyć pewne aspekty paraboli lotu piłki, zarówno przyspieszenie, jak i krzywiznę lotu. Gdy polowy jest w stanie z powodzeniem równoważyć przyspieszenie oraz krzywiznę toru lotu piłki, wówczas znajdzie się we właściwym miejscu o właściwym czasie i złapie piłkę. Dokładnie opisujemy to zagadnienie poniżej, ale już teraz warto zauważyć, że żadna ze strategii nie wymaga tego, by polowy przewidywał cokolwiek na temat przyszłego położenia piłki, a jedynie, by poruszał się w szczególny sposób względem jej aktualnego lotu, co stanowi przykład sterowania prospektywnego (np. Montagne i in. 1999).

Pierwsze rozwiązanie znane jest jako anulowanie wzrokowego przyspieszenia (ang. optical acceleration cancelation, OAC - np. Chapman 1968; Fink i in. 2009) i wymaga ustawienia się zgodnie z torem lotu piłki i biegu do momentu, gdy piłka będzie zdawała się poruszać ze stałą prędkością. Druga strategia nazywana jest liniową trajektorią wzrokową (ang. linear optical trajectory, LOT - np. McBeath i in. 1995) i wymaga od polowego, by poruszał się skośne względem lecącej piłki, aż wyda mu się, że piłka przemieszcza się po linii prostej. Wybór strategii działania zależy od miejsca, gdzie polowy znajduje się względem piłki (OAC działa najlepiej, gdy piłka leci prosto na zawodnika, a LOT pozwala na wychwycenie piłki lecącej pod kątem). 
Czy organizm faktycznie taczy i wykorzystuje opisane zasoby?

Strategia obliczeniowa sugeruje, że zapolowy pobiegnie po linii prostej do prawdopodobnego miejsca lądowania piłki. Uczyni tak, ponieważ obliczył przyszłe miejsce lądowania $\mathrm{w}$ oparciu o zmienne wejściowe, które wykrył, zanim zaczął biec. Skoro najkrótszy tor ruchu w kierunku wyznaczonego miejsca lądowania na otwartym terenie jest linią prostą, polowy powinien pobiec bezpośrednio do miejsca, w którym złapie piłkę. Zapolowi zazwyczaj nie biegają po linii prostej, co wyklucza strategię obliczeniową. LOT i OAC przewidują zarówno zakrzywienie linii ruchu polowego, jak i jej profil prędkości, którego celem jest zrównoważenie przyspieszenia piłki. Wyniki badań wskazują na stosowanie LOT (np. McBeath i in. 1995), ale istnieją również dowody, że OAC to strategia realistyczna i wykorzystywana w pewnych warunkach (np. Finki i in. 2009).

Powyższe rozwiązania posiadają liczne zalety, których nie posiada rozwiązanie obliczeniowe. Po pierwsze, zamiast polegać na wstępnym szacunku lotu piłki, który może być błędny, pozwalają polowemu, by mierzył swój ruch względem niej podczas poruszania się. Takie sprzężenie zawodnika i piłki umożliwia wykrycie i korektę błędnego toru ruchu. Po drugie omówione strategie dostarczają polowemu ciągłego strumienia informacji o tym, jak dobrze sobie radzi. Jeśli piłka nadal przyspiesza lub jej trajektoria jest zaokrąglona, wówczas informuje polowego o tym, że występuje błąd i jak go naprawić. Jeśli polowy biegnie najszybciej, jak to możliwe, i nadal nie jest w stanie poprawić błędów, to ma do czynienia z piłką niemożliwą do złapania, więc powinien zmienić cel i spróbować złapać piłkę po odbiciu. Własność afordancji - „łapalność" danej piłki - jest zatem określana tutaj przez informację wzrokową, bez odniesienia do wewnętrznej symulacji czy przewidywań.

\section{Podsumowanie}

Zarówno w LOT jak i OAC, rozmaite zasoby zadania (lot piłki, polowy, relacja między nimi określana przez kinematykę piłki widzianą przez poruszającego się obserwatora) zostały złożone $\mathrm{w}$ zorientowana zadaniowo jednostkę (Bingham 1988) przeznaczoną do wykonania aktualnego zadania (złapanie piłki). Tę jednostkę można uznać za inteligentna w sensie opisanym przez Runesona (1977), ponieważ wykorzystuje zalety lokalnych okoliczności zadania, by stworzyć surowe, ale zadaniowo zorientowane rozwiązanie (przykładowo: ani LOT, ani OAC nie stanowi ogólnego rozwiązania problemu). Najważniejszym wnioskiem, który należy wyciągnąć z tego przykładu, jest stwierdzenie, że relacja między informacją percepcyjną (o ruchu piłki) a organizmem (zapolowym) zastępuje potrzebę wewnętrznej symulacji fizyki lotu pocisku. 


\section{Ucieleśnienie w działaniu III.II: Błąd AB}

Co dzieci wiedzą o przedmiotach i ich własnościach oraz kiedy dochodzą do tej wiedzy? Piaget (1954) badał to zagadnienie, prosząc dzieci w różnym wieku o szukanie przedmiotów schowanych za przeszkodami w polu widzenia dziecka. Przed ukończeniem siódmego miesiąca życia dzieci nie szukają danego przedmiotu, zachowują się, jakby przestał istnieć. Od około 12 miesiąca dzieci przystępują do działania i odnajdują ukryty przedmiot, a więc wydaje się, że już rozumieją, że nawet jeżeli nie widzą zabawki, którą chcą dostać, to nadal można ją odnaleźć. Nabywając tę umiejętność, dzieci popełniają niezwykły „błąd”: po tym, gdy już kilkukrotnie sięgały po ukryty przedmiot w pierwszej lokalizacji, czyli A, nie udaje im się odnaleźć przedmiotu schowanego w lokalizacji B, nawet jeżeli dokładnie widziały, jak był on chowany. Zamiast tego ponownie sięgają do lokalizacji A (stąd nazwa „błąd AB”).

Istnieją różne standardowe kognitywne sposoby wyjaśniania tego błędu, ale wszystkie one w zasadzie zakładają, że (a) dziecko rozwinęło nieodzowne pojęcie przedmiotu, które opiera się na założeniu, że przedmiot nadal istnieje, nawet jeśli znika z pola widzenia, ale (b) coś w samej czynności sięgania uniemożliwia wiarygodne wykorzystanie tej wiedzy. Umiejętność niezbędną do wykonania owego zadania można zaobserwować, posługując się czynnością patrzenia jako miarą. Na przykład dzieci patrzą dłużej na czynność przenoszenia przedmiotu z punktu A do punktu B, co sugeruje, że wiedzą, że coś jest nie tak (np. Baillergeon i Graber 1988). Problem stanowi więc samo wykonanie czynności sięgania, ponieważ uzyskana wiedza nie zostaje wykorzystana w trakcie wykonywania czynności. Opisany podział czynność-umiejętność należy do często omawianych tematów w literaturze poznawczo-rozwojowej. Za główny cel badań tego typu przyjmuje się zrozumienie nadrzędnej umiejętności pozwalającej na przekształcenie wiedzy w działanie; aby to osiągnąć, należy opracować efektywne metody służące ominięciu potencjalnych przeszkód w prawidłowym wykonaniu czynności.

Thelen i inni (2001) zakwestionowali wszystkie aspekty takiego ujęcia problemu błędu $\mathrm{AB}$ w swoim ucieleśnionym modelu układu dynamicznego dla czynności sięgania. $\mathrm{W}$ tym przypadku model działania oparto na licznych eksperymentach zakładających odrzucenie podziału czynność-umiejętność i ponowne skoncentrowanie się na szczegółach wykonywanego zadania. Autorzy artykułu stwierdzili, że „błąd AB nie dotyczy tego, co niemowlęta maja czy też czego nie mają w formie pojęć trwałych, cech czy deficytów, ale tego, co robia i zrobily" (4). W rezultacie zaproponowane przez badaczy ujęcie błę$\mathrm{du} A B$ zastępuje wiedzę przedmiotową oraz brak właściwego wykonania czynności dynamiką postrzegania oraz działania w czasie i w kontekście realizacji zadania sięgania. 


\section{Jakie zadanie trzeba wykonać?}

To dość złożone pytanie. Klasyczna wersja zadania wymaga tego, by niemowlę patrzyło na to, jak przyciągająca uwagę zabawka zostaje schowana w położeniu A. Następnie dziecku pozwala się na kilkukrotne poszukiwanie i odnajdywanie tego przedmiotu, po czym jest on chowany w położeniu B. Zmiana położenia przedmiotu odbywa się w zasięgu wzroku dziecka.

Jedną z inspiracji do zastosowania ucieleśnionego ujęcia systemów dynamicznych było to, że - jak wiadomo - niemal każdy parametr tego zadania wpływa na działania niemowląt. Wśród tych parametrów znajduje się odległość do celów, odmienność zasłon, opóźnienie między chowaniem a szukaniem, przedmiot, którego dziecko szuka (jedzenie lub zabawka), kwestia tego, czy niemowlę jest poruszane i jak duże doświadczenie posiada w raczkowaniu (patrz: Thelen i in. 2001 - dokładny przegląd zagadnień). Jeśli błąd AB odzwierciedla wiedzę przedmiotową, to dlaczego te parametry są aż tak ważne?

Aby odpowiedzieć na to pytanie, Thelen i współpracownicy (2001) najpierw sporządzili listę szczegółów wchodzących w skład tego kanonicznego zadania (sekcja 2.2) i dzięki temu uzyskali jasne przedstawienie dostępnych zasobów, które mogą mieć wpływ na wykonanie danych czynności przez niemowlęta. Na początku zadania dzieci te dysponują wejściowymi danymi wzrokowymi o charakterze ciąglym (sekcja 2.2.1) z dwóch otworów w pudle umieszczonym w pewnej odległości od dziecka oraz jeden od drugiego. Eksperymentator przyciąga uwagę niemowlęcia, poruszając przedmiotem, po czym chowa go w otworze A. Te szczególne wejściowe dane wzrokowe (sekcja 2.2.2) wskazują na to, w którym otworze schowano przedmiot. Po krótkim zwlekaniu (sekcja 2.23) niemowlęta, zazwyczaj wtedy, gdy patrzą na wskazywaną lokalizację, wykonują kontrolowane wzrokowo sięganie (sekcja 2.2.4) po przedmiot. Sięganie to wymaga od nich, by zapamiętały (sekcja 2.2.5) położenie ukrytego przedmiotu w fazie zwlekania. Czynność ta zostaje kilkukrotnie powtórzona, aż do umieszczenia przedmiotu w lokalizacji B, po czym niemowlęta popełniają błędy w 70-80\% przypadków (zależnie od ich poziomu rozwojowego, sekcja 2.2.6).

\section{Jakie zasoby sa dostępne?}

W tej wersji zadania zasoby, które mogą mieć wpływ na jego wykonanie, obejmują ciągłe i specyficzne wyjściowe dane wzrokowe, długość opóźnienia oraz związek między opóźnieniem a czasową dynamiką zapamiętywania poprzednich sięgnięć. Niemowlę również wnosi własne zasoby do zadania. Wykonanie pożądanej czynności zależy na przykład od zdolności niemowlęcia do utrzymania uwagi wzrokowej oraz sposobu, w jaki dziecko wykonuje wzrokowo prowadzone sięganie. Thelen ze współpracownikami (2001) nie uznała pojęcia przedmiotu za jeden z zasobów dostępnych do wykonania zadania. To 
- jak się na pierwszy rzut oka wydaje - przeoczenie ma na celu sprawdzenie, w jakim stopniu badacze mogą modelować zachowania niemowląt bez przywoływania jakichkolwiek nadrzędnych umiejętności niezależnych od obserwowanych działań.

\section{Jak można połączyć zasoby, aby rozwiązać zadanie?}

Praca Thelen i współpracowników (2001) jest doskonałym przykładem wykorzystania hipotezy zastąpienia $\mathrm{w}$ poznaniu ucieleśnionym, ponieważ model wypracowany w tym badaniu wykorzystuje układy dynamiczne do wyjaśnienia tego, jak percepcyjne i ucieleśnione zasoby mogą zostać połączone i wytworzyć błąd, który pozornie wymaga wyjaśnienia reprezentacyjnego (pod postacią pojęcia przedmiotu u niemowląt). Wspomniany model określa dwa położenia $\mathrm{w}$ metrycznym polu przedstawiającym przestrzeń sięgania niemowlęcia oraz sposób zmysłowej percepcji kierunku sięgania. Dane wzrokowe aktywują działanie we właściwej lokalizacji w ruchowym polu planowania i doprowadzają do sięgnięcia we właściwym kierunku po przekroczeniu progu aktywacji. Planowanie kierunku sięgania przebiega nieustannie $\mathrm{w}$ czasie wykonywania czynności za pomocą kodowania populacyjnego (por. Georgopoulos 1995). Aktywacja w tym polu posiada dynamikę czasową, która uniemożliwia bezpośrednie wygaśnięcie działania, a pole planowanego ruchu „zapamiętuje” ostatnie zachowania. Aktywacje w różnych miejscach pola wchodzą w interakcję, umożliwiając współzawodnictwo i współpracę między elementami układu. Inicjowany jest model działania, a odpowiednie dane zostają wprowadzone do systemu. Zgodnie $\mathrm{z}$ opisanym modelem do podjęcia działania dochodzi w wyniku interakcji między rozmaitymi współzawodniczącymi układami dynamicznymi (konkretne dane wejściowe, dane zadania, pamięć, planowanie ruchu itd.), które działają w czasie i zmieniają kształt pola kontrolującego sięganie. Gdy dane wejściowe zostają przekierowane na lokalizacje B, pole ruchu przyjmuje kształt, który odzwierciedla współzawodnictwo między różnymi układami dynamicznymi, a percepcyjne dane wejściowe z położenia B zostają wbudowane $\mathrm{w}$ zupełnie inny system niż dane wejściowe z lokalizacji A. Działanie w tak zbudowanym systemie jest zatem odpowiednio inne. Jeśli parametry pasują do kanonicznej wersji zadania, w ramach modelu popełniany jest błąd AB. Należy zauważyć, że w specyfikacji modelu nie ma mowy o „pojęciu przedmiotu”, a jednak jest on zdolny do odtworzenia błędu $\mathrm{AB}$ - po prostu dzięki zastosowaniu systemu sięgania $\mathrm{z}$ jego własnościami dynamicznymi.

\section{Czy organizm rzeczywiście taczy i wykorzystuje te zasoby?}

Przedstawiony model znakomicie odzwierciedla zjawiska kluczowe dla zadania $\mathrm{AB}$ oraz pokazuje, $\mathrm{w}$ jaki sposób zmiany w szczegółach zadania (na przykład zmiany w opóźnieniach sięgania, zmiany własności przedmiotu) wpły- 
wają na jego wykonanie. W ramach koncepcji opartej na pojęciu przedmiotu zaproponowano rozwiązania dla przedstawionych efektów (zob. np. odpowiedź Diamonda 2001 na artykuł Thelen i in. 2001). Istnieją jednak inne aspekty wykonania danego zadania, których nie można do końca wyjaśnić za pomocą pojęcia przedmiotu. Co interesujące, zaprezentowany model przewiduje i wyjaśnia nowe odkrycie eksperymentalne, że błąd AB pojawia się pod nieobecność ukrytego przedmiotu (Smith i in. 1999). Jeśli nie ma przedmiotu, który trzeba zapamiętać, to wyjaśnienia oparte na pojęciu przedmiotu nie mogą posłużyć do odpowiedzi na pytanie, dlaczego błąd nadal się pojawia, skoro nie ma obiektu, który można by skonceptualizować. Natomiast w modelu ucieleśnionym przewiduje się, że „błąd” powstaje w wyniku nie w pełni wykształconej dynamiki sięgania, a nie $\mathrm{w}$ wyniku niekompletnego pojęcia przedmiotu. Takie spostrzeżenia sugerują, że możliwe jest wytworzenie błędu AB u starszych dzieci poprzez zwiększenie złożoności wymagań dla czynności sięgania. Zgodnie z tymi założeniami Smith (i in. 1999) oraz Spencer (i in. 2001) doprowadzili do wytworzenia się takiego błędu u dwulatków. Podobne „błędne” zachowania zaobserwowano u dzieci do 11 roku życia (Hund i Spencer 2003), a nawet u dorosłych (Spencer i Hund 2002). Nie można wyjaśnić występowania takich zachowań, posługując się pojęciem przedmiotu. Najlepszym sposobem na objaśnienie otrzymanych rezultatów jest przyjęcie założenia, że zaobserwowana czynność sięgania rzeczywiście jest wypadkową ucieleśnionej dynamiki zadania opisywanej w tym modelu.

\section{Podsumowanie}

Zadanie AB zazwyczaj wyjaśniano za pomocą narzędzi bazujących na standardowej teorii reprezentacji wewnętrznych w psychologii poznawczej. Wyjaśnienia te zakładają, że błędy w sięganiu są skutkiem niepełnego pojęcia przedmiotu, do którego niedojrzały system ruchowy ma ograniczony dostęp przed 12 miesiącem życia. Thelen i współpracownicy (2001) zastapili pojęcie przedmiotu ucieleśnioną dynamiką sięgania i chwytania, by z powodzeniem w ramach zaproponowanego modelu ująć szeroki zakres efektów kontekstowych oraz wyjaśnić nowe wersje błędu $A B$, bez schowanych przedmiotów, występujące u starszych dzieci.

\section{Hipoteza konceptualizacji w ucieleśnieniu: Pojęcia i ich ugruntowanie}

Zdefiniowaliśmy refleksję nad poznaniem ucieleśnionym jako rodzaj badań połączonych podstawową strategią badawczą, która nakazuje (1) ustalić, jakie zadanie należy wykonać; (2) określić zasoby dostępne w przestrzeni tego zadania, które mogą pomóc organizmowi rozwiązać je; (3) wygenerować hipotezę dotyczącą tego, jak te zasoby są łączone i koordynowane (na przykład budując model na podstawie postawionych hipotez; patrz Bingham 2001, 2004a,b 
- inny przykład; Golonka i Wilson 2012 - dokładna analiza tego modelu); i na koniec (4) zbadać empirycznie, czy ludzie rzeczywiście wykorzystują połączone w dany sposób zasoby. Nie jest to jednak jedyna forma badań nad zjawiskiem ucieleśnienia, dlatego też należy zapytać, na jakiej podstawie wykluczamy inne badania z naszej klasyfikacji.

Większość przykładowych badań wykorzystuje założenie nazwane przez Shapiro (2011) hipoteza konceptualizacji. Jest to hipoteza głosząca, że pojmowanie świata jest osadzone w systemach percepcji-działania i ograniczone przez ich naturę (specyfikę ludzkiego ciała). Na przykład Lakoff i Johnson (1980, 1999) opisują, jak powszechnie stosowane metafory są zazwyczaj osadzone w naturze naszych ciał i doświadczeń w świecie (przyszłość jest $z$ przodu, siła jest $u$ góry, a relacje są podróżą). Celem tej formy badań nie jest zastąpienie pojęć innymi procesami. Zamiast tego, poszukuje się przykładów, w których wykorzystanie pojęć może być utrwalane lub zakłócane przez manipulowanie stanem osadzenia ciała w świecie.

W literaturze istnieje wiele współczesnych przykładów badań tego typu. Na chwilę skoncentrujemy się na dwóch reprezentatywnych. Pierwsze z nich zakłada przedstawienie sposobu, $\mathrm{w}$ jaki stan ciała wpływa na nasz dostęp do reprezentacji umysłowych przy szacowaniu wielkości (Eerland i in. 2011), a drugie bada zjawisko o odwrotnych efektach, obejmując wpływ przedstawień umysłowych na stan ciała, w którym stan umysłu jest przypuszczalnie osadzony (Miles i in. 2010).

Pochylenie się w lewo powoduje, że wieża Eiffla wydaje się mniejsza

Ludzie są w stanie generować sensowne szacunki wielkości rzeczy, takie jak wysokość Wieży Eiffla, nawet jeśli nie znają dokładnej odpowiedzi. Uważa się, że to szacowanie zachodzi dzięki reprezentacjom umysłowym wielkości uporządkowanych na wzór osi liczbowej, z małymi liczbami po lewej stronie, a większymi po prawej (Restle 1970). W badaniach autorstwa Eedland i współpracowników (2011) poproszono uczestników, by stali, jednocześnie lekko balansując $w$ lewo lub prawo względem środka własnego ciała, aby sprawdzić hipotezę, że w rezultacie odchylenia postawy liczby z prawego lub z lewego końca osi wydają się bardziej dostępne. Gdyby tak było, wówczas badani, posługując się reprezentacjami umysłowymi, powinni generować niższe wielkości szacunkowe, gdy wychylają się w lewo, a większe przy ruchu w prawo.

Wyniki były mieszane. Gdy osoby badane wychylały się w lewo, szacowane przez nie wielkości zwykle były w nieznacznym stopniu mniejsze niż wtedy, gdy wychylały się w prawo. Autorzy badania doszli więc do wniosku, że dane potwierdzają postawioną przez nich hipotezę: dostęp do umysłowej konceptualizacji osi liczbowej, ułożonej od lewej do prawej, jest częściowo osadzony w przechylaniu się ciała z lewej strony na prawą. Należy jednak zauważyć, że 
zmiana rozmiaru szacunku była bardzo mała i rezultatów tych nie zaobserwowano w odniesieniu do wszystkich kwestii. Analogiczne zjawisko nie występowało przy wychyleniu w prawo.

\section{Myślenie o przyszłości skutkuje wychyleniem się do przodu}

Drugim przykładem badań $\mathrm{w}$ duchu konceptualizacji jest praca Milesa i współpracowników (2010), którzy próbowali dociec, w jaki sposób ludzie odbywają „umysłowe podróże w czasie”, myśląc zarówno o przyszłych, jak i o przeszłych zdarzeniach. Naukowcy postanowili zmierzyć zmiany w odchyleniu podstawy ciała na wysokości kolan i odkryli, że gdy badani myśleli o przyszłości, to przechylali się do przodu (przyszłość jest $z$ przodu). A gdy uczestnicy badania myśleli o zdarzeniach z przeszłości, ich ciała były zazwyczaj odchylone do tyłu (przeszłość jest $z$ tyłu). Ponownie okazało się, że uzyskane różnice w odchyleniu były znikome (występowało odchylenie o około $2 \mathrm{~mm} \mathrm{w}$ każdym kierunku), co jednak nie przeszkodziło autorom wyciągnąć wniosku, że ich wyniki wykazały związek między stanem ciała i treściami poznawczych przedstawień czasu.

\section{Gdzie jest ucieleśnienie?}

Żadne z powyższych badań nie rozpoczyna się od analizy zadania ani od rozważenia, jakie ucieleśnione i percepcyjne zasoby można wykorzystać do rozwiązania tego zdania. Takie sformułowanie projektu badawczego wyklucza możliwość odkrycia potencjalnej roli dostępnych zasobów w procesie poznania. Oba badania opierały się na założeniu, że wyznaczone zadanie rozwiązywane jest wewnętrznie, reprezentacyjnie, za pomocą procesów poznawczych, które można modyfikować lub które mogą zostać zmodyfikowane przez stan ciała. W proponowanych mechanizmach rozwiązywania zadania nie uwzględniono nieodzownej, krytycznej oraz konstytutywnej roli ciała i środowiska, tak jak w przypadku innych omawianych prac. Nie da się złapać piłki bez poruszania się. Ruch polowego w sposób nieunikniony tworzy informacje dostępne zarówno dla LOT, jak i OAC, które następnie wpływają na obserwowane zachowanie. Nie można rozwiązać zadania $A B$ bez sięgania. Fizyczne sięganie przywołuje dynamikę wzrokowo kierowanego sięgania, a następnie kształtuje obserwowane zachowanie. Można jednak odchylić się w lewo i nie zmienić szacowanych wielkości, można też myśleć o przyszłości bez wychylania się do przodu. Konceptualizacyjne podejście w badaniach nad ucieleśnieniem nie polega na definiowaniu ciała jako zasobu kluczowego dla zadania ani nie stwarza żadnego formalnego ujęcia tego, jak ciało kształtuje część rozwiązania właściwą dla danego zadania. W najlepszym wypadku wskazuje, że czasami myśli i działania idą w parze. 


\section{Wykonując kolejny krok - ucieleśniona analiza języka}

W niniejszym artykule zaprezentowaliśmy strategię badawczą, którą uważamy za niezbędną dla rozwoju właściwie rozumianej kognitywistyki ucieleśnionej. Przeanalizowaliśmy zmiany w istniejących badaniach, które posługują się tą strategią, poczynając od prostych systemów robotycznych, przez zachowania pozaludzkie, zwierzęce, a kończąc na dwóch przypadkach zachowania ludzkiego: prostego systemu postrzegająco-działającego (łapanie lecącej piłki) oraz bardziej tradycyjnego zadania poznawczego (zadania AB). Naszym celem było wykazanie, że takie ujęcie problemu okazuje się produktywne w przypadku wielu różnorodnych zadań i zachowań oraz wykazuje ciągłość działań agentów w rozumieniu biologicznych teorii ewolucyjnych.

W zakończeniu niniejszego artykułu zamierzamy podjąć wstępną próbę ucieleśnionej analizy klasycznego zadania poznawczego - języka. Naszym celem jest postawienie pierwszego kroku: zidentyfikowanie natury kluczowych zasobów obecnych w zdarzeniu językowym, a w szczególności - formy i treści informacji językowej. Takie działania mogą posłużyć jako narzędzia wykorzystywane do prowadzenia i ograniczania nieprzedstawieniowych badań empirycznych, które - jak mamy nadzieję - zostaną przeprowadzone w przyszłości.

\section{Język: wyjątkowy, ale nie magiczny}

Większość psychologów zakłada, że łapanie lecącej piłki i mówienie o niej to dwa różne rodzaje zadań, dlatego też nie można używać narzędzi przystosowanych do analizowania czynności łapania piłki w badaniach zajmujących się komunikacją językową. Język to jeden z niezwykle interesujących rodzajów zachowań, posiadający pewne własności, które czynią go wyjątkowym. Ale język sam w sobie nie wykazuje cech magicznych, jest produktem ewolucji, tak samo jak pozostałe formy zachowania, toteż całkowicie sensowne wydaje się założenie, że będzie on podatny na analizy badawcze, które sprawdziły się $\mathrm{w}$ innych dziedzinach. Innymi słowy naszym pierwszym ruchem jest stwierdzenie, że problemy percepcyjno-działaniowe oraz językowe to zagadnienia tego samego rodzaju.

Jak dowodzimy w dalszej części artykułu, istnieje jednak istotna różnica, którą należy wziąć pod uwagę, jeśli chodzi o proces nadawania znaczenia informacjom percepcyjnym i językowym. Różnicę tę można zauważyć tylko trzecioosobowo, w toku naukowej analizy sytuacji. Posługując się pojęciem ucieleśnienia, nie należy nigdy zapominać, że w tym podejściu próbuje się wyjaśnić pierowszoosobowe doświadczenie organizmu (jak przekonująco wykazał Berrett 2011) i z tej perspektywy nie ma zupetnie różnicy między tymi dwoma typami informacji. W życiu codziennym organizm nigdy nie może „zajrzeć za kurtynę”, ponieważ kinematyczne wzorce umieszczone w szyku energetycz- 
nym to wszystko, do czego mamy dostęp. Zadaniem uczącego się organizmu jest wykrywanie tych wzorców i poznanie ich znaczenia poprzez wykorzystanie informacji zdobytych w działaniu. Jeżeli danej informacji można użyć, by złapać lecącą piłkę, to da się również pokazać, jakie znaczenie ma ta informacja. Analogicznie można wykorzystać informację językową, by poprawnie odpowiedzieć na pytanie interlokutora, ponownie posługując się znajomością znaczenia informacji. Zasadniczy proces działania jest taki sam. Trzeba nauczyć się wykrywać odpowiednią strukturę i we właściwy sposób ją wykorzystywać.

\section{Jak informacja zyskuje znaczenie}

Zdarzenia w świecie można rozróżnić dzięki ich podstawowej dynamice wytwarzającej wzorce kinematyczne $\mathrm{w}$ szykach energetycznych. Wspomniane wzorce mogą służyć jako informacje percepcyjne dotyczące układu dynamicznego, który je wytworzył (Bingham 1995). W przypadku percepcji struktura szyku energetycznego jest wynikiem dynamiki zdarzeń w świecie, w którym doszło do wytworzenia tej struktury w danym momencie (przykładowo informacja optyczna wysyłana przez ruch lecącej piłki dotyczy ruchu lecącej piłki). Sprzężenie struktury szyku energetycznego i dynamiki zdarzeń zależy od praw ekologicznych (Turvey i in. 1981), zatem wykrywanie informacji pozwala organizmowi na dynamiczne postrzeganie zdarzenia.

Każde zdarzenie językowe (mowa, pisanie, gesty) również wytwarza strukturę w szyku energetycznym (mowa tworzy struktury akustyczne, pisanie i gesty struktury optyczne). Organizm posługujący się językiem może wykorzystać tę strukturę jako informacje językowe, a ponieważ traktujemy je jako dane tego samego rodzaju, możemy analizować informację językową w ten sam sposób, w który analizujemy informację percepcyjną. Jedyną różnicą między informacją percepcyjną a językową jest związek między strukturą matrycy energetycznej a znaczeniem informacji. $\mathrm{W}$ języku struktura szyku energetycznego nie oznacza dynamiki na przykład artykulacji, ale dotyczy tego, co oznaczają słowa. Struktura wypowiedzi zyskuje znaczenie dzięki konwencjom społecznym obowiązującym w danym środowisku językowym, więc można uznać, że uczymy się konwencjonalnego znaczenia obowiązujących wzorców. Skonwencjonalizowane podstawy zapewniają stabilność informacji językowej, z zastrzeżeniem, że należy rozróżniać prawa oraz konwencje językowe. Konwencje mogą się zmieniać, a wraz z nimi znaczenia słów, język jest zdecydowanie mniej stabilny niż percepcja. Obniżona stabilność jest oczywiście faktem językowym, który trzeba wyjaśnić, więc może zaproponowana przez nas analogia nie jest całkowicie niepoprawna. 


\section{Czy potrzebujemy reprezentacji?}

W tym punkcie rozważań najczęściej korzysta się ze standardowego podejścia $\mathrm{w}$ kognitywistyce, zgodnie $\mathrm{z}$ którym konwencjonalne znaczenie wymaga wsparcia reprezentacyjnego. Informacja językowa wytwarzana jest przez podjęcie działania w złożonym układzie dynamicznym w czasie teraźniejszym, ale znaczenie tej informacji jest konwencjonalne i może dotyczyć spraw $\mathrm{w}$ tym czasie niedostępnych. Można rozmawiać o rzeczach niedostępnych bezpośrednio, w sposób, który nie ma swojej analogii w percepcji. W jakim więc sensie należy rozumieć znaczenie informacji językowej, jeśli nie w formie wewnętrznych modeli ludzi, przedmiotów, miejsc i tak dalej, do których odnoszą się dane słowa?

Przedstawiony problem jest w pewnym stopniu wypadkową formy pytania. Zadanie pytania o to, co znaczy słowo, zakłada istnienie czegoś statycznego i wewnętrznego - słowa maja znaczenia. Zamierzamy zatem zadać to samo pytanie w inny sposób. Jak już wspomnieliśmy wcześniej, jeśli ktoś potrafi poprawnie zareagować w odpowiedzi na informację językową, należy wówczas stwierdzić, że osoba ta wie, co znaczy owa informacja. Zamiast pytać, jak poznajemy znaczenia słów, powinniśmy zapytać o to, jak uczymy się odpowiadać na informację językową. Czy można właściwie zareagować w odpowiedzi na taką informację bez przetwarzania reprezentacji umysłowych? Jak wykazaliśmy w poprzedniej części artykułu dotyczącej robotyki, całkiem interesujące i złożone zachowania mogą być wytwarzane bez wykorzystania wyraźnie zarysowanych modeli wewnętrznych tych zachowań. Żaden z robotów nie korzystał z języka.

W percepcji, jak sądzimy, przedstawienia wewnętrzne nie są konieczne, gdyż szczególny związek między informacją percepcyjną a światem sprawia, że postrzeganie informacji staje się postrzeganiem świata (Gibson 1966, 1979; Turvey i in. 1981). Przyjęcie takiego założenia oznacza, że organizm może właściwie zareagować w odpowiedzi na informację percepcyjną bez potrzeby poznawczego wzbogacania danych wejściowych, które zebrał w procesie percepcji. Zasadniczym zagadnieniem w przypadku języka jest kwestia, czy konwencjonalne relacje informacji językowej i ich znaczenia można uznać za wystarczające wsparcie dla czegoś takiego jak percepcja bezpośrednia.

Chemero (2009) przedstawił rozbudowaną argumentację wspierającą twierdzenie, że konwencje są w tym przypadku wystarczające, a nawet zasugerował, że informacje percepcyjne mogą być osadzone w konwencji. Autor ten używa pojęcia konwencji zaczerpniętego z semantyki sytuacyjnej Barewise'a i Perry'ego (1983); także naszym zdaniem analizę tego rodzaju można uznać za punkt wyjścia w przyszłych badaniach. Podsumowując kwestie kluczowe, można powiedzieć, że Barewise i Perry wysunęli stwierdzenie, że informacja zostaje wytworzona na potrzeby organizmów przez sytuacje. Dana sytuacja jest później przekształcana w przykład (wzór) typu sytuacji, a różne sytuacje 
mogą być ze sobą łączone przez ograniczenia. Jeżeli dwa typy sytuacji - S1 i S2 - są połączone dzięki ograniczeniu, to wzór S2 informuje o wzorze S1 dzięki temu ograniczeniu. Organizm ma dostęp do takiej informacji wtedy i tylko wtedy, gdy ma dostęp do jednego z wzorów sytuacji oraz danego ograniczenia sytuacyjnego. Tak właśnie wygląda przypadek języka. Jeżeli S1 jest „omawianą sytuacją”, a S2 - „zdarzeniem językowym w dyskusji”, można uznać, że są one ograniczeniami danego środowiska językowego. W tym ujęciu wzór S2 (np. wypowiedź „deszcz w Hiszpanii pada zwykle na nizinie”) niesie ze sobą informację o wzorze S1 (typowym rozmieszczeniu opadów deszczu w Hiszpanii), ale jedynie dla wprawnego użytkownika języka [polskiego]. Natomiast gdyby wypowiedź przybrała formę la lluvia en España se mantiene principalmente en la llanura, wówczas użytkownik języka [polskiego] nie dotarłby do informacji o wzorze S1, ponieważ nie ma dostępu do istotnych ograniczeń w języku hiszpańskim. Semantyka sytuacyjna dostarcza języka formalnego, który pozwala na mówienie o tym, jak informacja językowa może informować o świecie nawet pomimo tego, że jest oparta na konwencji. W tej kwestii pozostaje wiele do zrobienia, jak jednak zauważa Chemero (2009), tak zakreślony obszar badań pozwala na traktowanie szczegółowych i konwencjonalnych informacji jako zjawisk tego samego rodzaju i dzięki temu wydaje się dobrym punktem wyjścia dla nieprzedstawieniowych badań nad znaczeniem języka.

Warto powiedzieć stanowczo, że wysunięcia argumentów przeciwko konieczności wspierania języka reprezentacjami nie można uznać za tożsame z przyjęciem założenia, że mózg nie odgrywa żadnej roli w komunikacji językowej. Mózg bez wątpienia jest częścią całego procesu (tak jak w przypadku postrzegania/działania), a ucieleśnione ujęcie języka powinno się zmierzyć z tym faktem, o ile hipotezy o działaniu mózgu okażą się spójne ze stosowaną tu ucieleśnioną analizą. Na przykład można się powołać na literaturę opisującą sprzężenie między artykulacją a dynamiką neuronalną, które współtworzy mechanizm rozumienia języka. Prace tego rodzaju koncentrują się wokół zagadnień związanych $\mathrm{z}$ wytwarzaniem sylab i modeli zgodnie z zasadami dynamiki oscylacyjnej. Otrzymane zmienne można następnie połączyć z dynamiką oscylacyjną kory mózgowej (Luo i Poeppel 2007; Giraud i Poeppel 2012; Peelle i Davis 2012). Wśród naukowców zajmujących się tym zagadnieniem nie ma zgody co do tego, czy sylaby stanowią właściwy poziom analizy fonetycznej (Cunnins 2012), jednak mimo braku wiążących dowodów naukowych przedstawiona forma argumentu o udziale mózgu w procesie rozumienia języka jest spójna z niektórymi częściami zaproponowanej przez nas analizy. Przyjęte ramowe założenia wskazują na sposób połączenia informacji językowej z dynamiką kory mózgowej. $\mathrm{Z}$ tego powodu w zasadzie nie ma potrzeby odwoływania się do reprezentacji, by wyjaśnić, jak informacja językowa może doprowadzić do podjęcia działania. Naszym zdaniem jako nieprzedstawieniową alternatywę dla reprezentacji można zaproponować nieliniowy system dynamiczny, w którym struktury szyku energetycznego (w formie informacji 
percepcyjnych i językowych) wywołują zmiany w dynamice kory sprzężonej z kończynami, ustami i tak dalej, zdolnymi do podjęcia działania. Działanie (poruszanie się, mówienie) powoduje zmiany w środowisku odbioru informacji percepcyjnej i/lub językowej, które z kolei wpływają na dynamikę kory mózgowej.

\section{Język, choć szczególny, jest podatny na ucieleśnione analizy}

Tworzymy informację językową (np. mówiąc lub pisząc tekst), aby osiągnąć konkretne cele (np. kierowanie i regulowanie zachowania własnego i innych). W systemie dynamicznym informacja językowa zostaje wytworzona dzięki sprzężonej dynamice artykulatorów i mózgu umiejscowionych w społecznie określonym środowisku językowym o specyficznych własnościach dynamicznych. Zatem dynamika języka przybiera formę złożonej wypadkowej wielu sprzężonych systemów dynamicznych, ale informacja językowa zostaje wytworzona przez dynamiczne zdarzenie, podobnie jak informacja percepcyjna; nie są to różne rodzaje informacji.

Informacje językowe są kluczowym zasobem w działaniu i odgrywają rolę równie ważną jak informacje percepcyjne. Co więcej - uważamy, że podobieństwa istniejące między tymi dwoma rodzajami informacji są wystarczająco wyraźne, by wykorzystać metody analizy percepcji do analizy języka. Kluczowa zbieżność między tymi rodzajami informacji jest taka, że z pierwszoosobowej perspektywy postrzegajacego oraz działajacego użytkownika języka uczenie się znaczeń informacji językowych $i$ uczenie się znaczeń percepcyjnych to ten sam proces. Różnice $\mathrm{w}$ zachowaniu oparte na wspomnianych dwóch typach informacji (niezwykle ważne) wyrastają z różnic w sposobie, $\mathrm{w}$ jaki te informacje powstają i łączą się ze swoim znaczeniem. Podobieństwa między informacjami językowymi a percepcyjnymi wskazują na to, że w badaniach nad wykorzystywaniem informacji w postrzeganiu znaczenia to samo podstawowe podejście można zastosować do analizy zarówno języka, jak i percepcji-działania, co jest samo w sobie znaczącym krokiem naprzód.

Wprawdzie nie ulega wątpliwości, że język jest krokiem milowym w rozwoju złożonych systemów dynamicznych, jednak zasadnicza forma analizy informacji percepcyjnych i językowych powinna pozostać taka sama. Informacje językowe pełnią funkcję zasobu zadaniowego dokładnie tak jak informacje percepcyjne, powinniśmy badać je tak, jakbyśmy próbowali ustalić ich znaczenie w swego rodzaju urządzeniu zorientowanym zadaniowo, które organizm wytwarza, aby rozwiązać dany problem. Naszym zdaniem należy najpierw wyczerpać wszystkie możliwości tej strategii działania, zanim pochopnie wyciągnie się wniosek, że nie da się tego zrobić bez reprezentacji wewnętrznych, z których wiele systemów poznawczych zdaje się nie korzystać. 


\section{Inne ucieleśnione ujęcia języka: parę uwag na temat ugruntowania}

Zaproponowana przez nas strategia badawcza nie jest pierwszą próbą ucieleśnienia języka. Wcześniejsze wysiłki w tym kierunku, przedstawione w poprzednich sekcjach artykułu, można zaklasyfikować jako w dużym stopniu zbieżne z hipotezą konceptualizacyjną, której wybrane problemy omówiliśmy powyżej (patrz: Willems i Fracken 2012). W badaniach nad ucieleśnieniem najczęściej stawia się hipotezę, że znaczenie jest ugruntowane w symulacji poprzednich doświadczeń, która zawiera ich ucieleśnione elementy. Zadania mierzące rozumienie znaczenia powinny odzwierciedlać obecność tego rodzaju symulacji (Barsalou 1999). Dwie głośne próby mierzenia efektów ucieleśnionych symulacji to efekt kompatybilności zdania-działania (np. Glenberg i Kaschak 2002) oraz zadanie weryfikacji zdania-obrazu (np. Stanfield i Zwaan 2001).

\section{Kompatybilność działanie-zdanie}

Glenberg i Kaschak (2002) poprosili uczestników badania o ocenę sensowności zestawu zdań. W niektórych z tych zdań implikowano bezpośredni ruch (np. „zamknij szufladę” - zakłada ruch ze strony badanego). Uczestnicy odpowiadali przez wciśnięcie guzika, więc wykonywany przez nich ruch był zgodny lub nie z kierunkiem implikowanym w zdaniu. Badani szybciej wciskali guzik, jeśli kierunek odpowiedzi i ten implikowany były zgodne, a wolniej, kiedy nie były. Zdaniem autorów zachowane takie pokazuje, że ludzie umysłowo symulują działanie ze zdania po to, by je zrozumieć. Ich zdaniem „rozumienie języka jest ugruntowane w działaniach cielesnych” (Glenberg Kashak 2002: 562).

\section{Zadanie weryfikacji zdania}

Z kolei Stanfield i Zwaan (2001) testowali hipotezę symulacji, badając reakcję uczestników badania na zdania implikujące położenie przedmiotu. Na przykład wypowiedź „ołówek jest w kubku” zakładała położenie pionowe, a „ołówek jest w szufladzie" - poziome. Następnie pokazywali badanym obrazki przedstawiające przedmioty $\mathrm{w}$ położeniu zgodnym i niezgodnym [ze zdaniem], a następnie prosili o zweryfikowanie, czy przedstawiony przedmiot pasuje do zdania. Badani reagowali szybciej w warunkach zgodności, a wolniej w przypadku jej braku.

Głównym problemem tego rodzaju badań jest założenie, że całą ciężką pracę wykonuje się w głowie, a percepcja i działanie jedynie modyfikują jej wyniki. Zanim dowiemy się czegoś ważnego na temat rozumienia języka dzięki takim badaniom, musimy włożyć więcej wysiłku w próbę odpowiedzi na kilka podstawowych pytań. Badania tego typu nie opisują szczegółowo zasobów dostępnych podczas [wykonywania] zadania przedłożonego uczestnikom, a to 
jest niezwykle istotna część procesu rozumienia zadania z perspektywy badanych. Nie wiadomo na przykład, jaka jest treść informacyjna obrazu przedmiotu, na czym polega dynamika czynności wciskania guzika (czy też innych wykorzystywanych rodzajów odpowiedzi) ani jaka relacja zachodzi między tymi dwoma obiektami - co się dzieje, kiedy staramy się kontrolować wykonywaną czynność, posługując się dostępnymi treściami informacyjnymi? To nie są proste pytania. Już Gibson zauważył, że dokładne przedstawienie właściwej treści informacyjnej danego obrazka jest zadaniem niezwykle trudnym (1979). Bez zabiegów tego rodzaju nie można próbować wyjaśnić, jak słyszenie różnych zdań wpływa na wciśnięcie guzika w odpowiedzi na bodziec wzrokowy w formie obrazu. Być może zależności wykazane w badaniach rzeczywiście istnieją, w końcu te same wyniki osiągano wielokrotnie. Jednak historię tę dopiero trzeba opowiedzieć, i podobnie jak w kwestii pozostałych omówionych tu prac uważamy, że udzielenie odpowiedzi na te pytania najprawdopodobniej doprowadzi do zastąpienia umysłowych symulacji odpowiednią dynamiką zdefiniowaną $\mathrm{w}$ analizie zadania.

\section{Wnioski}

Na początku dwudziestego wieku niemiecki nauczyciel Wilhelm von Osten miał konia o imieniu Hans. Koń ten, jak twierdził von Osten, potrafił liczyć i wykonywać proste zadania matematyczne. Hans prezentował swoje zdolności przez szereg lat podczas darmowych występów. Dopiero psycholog Oskar Pfungst gruntownie zwerifykował zapewnienia von Ostena i wyjawił prawdę na temat zdolności konia: Hans nie znał matematyki, ale wiedział, kiedy ma przestać uderzać kopytem, gdy jego właściciel pokazał, że koń „uzyskał” właściwą odpowiedź (w widoczny sposób, ale podświadomie rozluźniając mięśnie; von Osten nie był oszustem). Uważa się, że wiedza abstrakcyjna, taka jak dodawanie, wymaga pewnej formy wewnętrznych stanów przedstawieniowych, ale w tym wypadku wyjaśnienie poznawcze (teza, że Hans posiadał wewnętrzną umiejętność liczenia) zastąpiono wyjaśnieniem [opartym na] prostym sprzężeniu percepcyjnym ze środowiskiem.

Od tego czasu historia Mądrego Hansa funkcjonuje w psychologii jako przestroga przed pochopnym wyciąganiem wniosków. Rozpoznanie zastosowanego przez organizm praktycznego rozwiązania problemu wymaga wzięcia pod uwagę wszystkich potencjalnych rozwiązań zadania, które następnie należy sprawdzić eksperymentalnie, by dowiedzieć się, które z dostępnych możliwości są rzeczywiście wykorzystywane. W tej kwestii niewiele się zmieniło od roku 1907, w którym Pfungst przeprowadzał swoje testy.

W standardowym podejściu kognitywistycznym istnieją dwie powiązane przeszkody uniemożliwiające określenie, które rozwiązania są wykorzystywane. Jedna $\mathrm{z}$ nich to niedostatek bodźca i wynikająca $\mathrm{z}$ niego potrzeba we- 
wnętrznego przedstawieniowego wzbogacenia percepcji. Przedmioty i procesy opisywane w standardowej psychologii poznawczej mają konkretne zadanie do wykonania, które hipotetycznie zakłada istnienie potrzeby wzbogacenia informacji percepcyjnej. Przyjęcie takich założeń oznacza, że w prowadzonych badaniach kognitywistycznych nigdy nawet nie brano pod uwagę sprawdzenia rzeczywiście ucieleśnionych alternatywnych rozwiązań, które jak obecnie wiadomo - są bardzo prawdopodobne z naukowego punktu widzenia.

W badaniach nad poznaniem ucieleśnionym, w których wykorzystywany jest model wyjaśniania zainspirowany hipotezą zastąpienia, odrzuca się te założenia i analizuje zasoby dostępne w środowisku. Zasoby te mogą wspierać złożone zachowania, a poza tym - co ważne - bada się tutaj również sposób, $\mathrm{w}$ jaki zdobyte informacje mogą służyć ich wzajemnemu powiązaniu. Jednym z ważniejszych osiągnięć ostatnich czterdziestu lat było odkrycie istnienia bogatych i różnorodnych informacji w środowisku (Gibson 1966, 1979) ${ }^{12}$, które można wykorzystać w celu wytwarzania wszelkiego rodzaju złożonych zachowań. Dostępność informacji percepcyjnych wysokiej jakości wyklucza konieczność powoływania się na wszelkie dodatkowe konstrukty poznawcze w celu wyjaśnienia badanych zachowań. Nasze zachowania przybierają formę jednej z możliwości dostępnych $\mathrm{w}$ puli potencjalnych zasobów zadaniowych, w skład których wchodzi ciało, środowisko i oczywiście mózg. Rzetelna analiza to podstawowy warunek, który należy spełnić, by odkryć, które z dostępnych zasobów i relacji między nimi kształtują rozwiązanie stosowane w danym zadaniu.

To prawda, że badania nad poznaniem ucieleśnionym prowadzone z wykorzystaniem hipotezy zastąpienia nie mogą obecnie wyjaśnić wszystkich zachowań (Shapiro 2011). Nawet najbardziej entuzjastycznie nastawieni badacze poznania ucieleśnionego sądzą, że istnieją problemy, które charakteryzuje swego rodzaju „głód reprezentacji”, ponieważ nie da się ich rozwiązać bez przedmiotów czy procesów wykorzystywanych w standardowym podejściu kognitywistycznym (Clark i Toribo 1994). Najczęściej podawanym przykładem takiego problemu jest język. Sądzimy jednak, że należy być bardziej optymistycznym w tej kwestii. Na razie możemy jedynie wyciągnąć wniosek, że badania nad poznaniem ucieleśnionym oparte na hipotezie zastąpienia jeszcze nie są w stanie wyjaśnić zagadnień tego rodzaju. Jesteśmy przekonani, że nie istnieje nadrzędna przyczyna, która powoduje, że tych zachowań nie da się wyjaśnić za pomocą rozwiązań zainspirowanych hipotezą zastąpienia w poznaniu ucieleśnionym - z uwagi na fakt, że najtrafniejszym opisem zachowania człowieka, jak uważamy, jest stwierdzenie, że istota ludzka jest zbiorem

\footnotetext{
${ }^{12}$ Barrett (2011), Chemero (2009) i Shapiro (2011) rozwijają tezę, że zaproponowana przez Gibsona analiza percepcji wzrokowej stanowi podstawę dla większości literatury dotyczącej poznania ucieleśnionego.
} 
postrzegających, działających i alinearnych układów dynamicznych realizujących procedurę zastąpienia. Nasz optymizm motywujemy sukcesami badawczymi, które opisaliśmy w niniejszym artykule, a w szczególności faktem, że kiedy uwaga badaczy już była skierowana na problemy charakteryzujące się „głodem reprezentacji”, to ich badania istotnie zakończyły się powodzeniem. Najlepszym przykładem działań potwierdzających powyższe jest ucieleśniona analiza błędu AB, w której dosłownie zastępuje się „myślenie o niedostępnych przedmiotach” działaniem ucieleśnionym. Za kolejny przykład może posłużyć praca dotycząca pająków z rodzaju Portia (patrz powyżej; więcej informacji w: Barrett 2011). Zaproponowaliśmy również kolejny krok naprzód w zakresie wstępnej analizy języka, która zastępuje znaczenie słów działaniem, na jakie nam język pozwala. Jednak dopiero okaże się, czy zaproponowane przez nas rozwiązanie jest właściwe (por. Port i Leary 2005; więcej informacji na temat badań nad językiem w: Port 2007).

Zastosowanie modelu zastąpienia $\mathrm{w}$ badaniach nad poznaniem ucieleśnionym doprowadziło do wytworzenia metod i narzędzi formalnych (głównie w formie modeli systemów dynamicznych), a zasadność wykorzystywanego podejścia wielokrotnie potwierdzono już empirycznie. Wyjaśnienia stosowane we wspomnianych badaniach sytuują ucieleśnienie w centrum rozwiązań stosowanych przez organizm w odpowiedzi na dane zadanie, a nie na ich marginesie. Naszym zdaniem badania takie $\mathrm{w}$ pełni zasługują na miano badań nad poznaniem ucieleśnionym.

\section{Literatura}

Adam, H. i Galinsky, A. 2012. Enclothed cognition. Journal of Experimental Social Psychology 48: 918-925.

Baillargeon, R. i Graber, M. 1988. Evidence of a location memory in 8-month old infants in a non-search A-not-B task. Developmental Psychology 24: 502511.

Ballerini, M., Cabibbo, N., Candelier, R. i in. 2007. Interaction ruling animal collective behaviour depends on topological rather than metric distance: evidence from a field study. Proceedings in National Academy of Science 105: 1232-1237

Barrett, L. 2011. Beyond the Brain: How the Body and the Environment Shape Cognition. New Jersey: Princeton University Press.

Barsalou, L. W. 1999. Perceptual symbol systems. Behavioral and brain sciences. 22: $577-660$.

Barwise, J. i Perry, J. 1983. Situations and Attitudes. Cambridge, MA: MIT Press. 
Beer, R. D. 2003. The dynamics of active categorical perception in an evolved model agent. Adaptive Behavior 11: 209-243.

Bingham, G. P. 1988. Task-specific devices and the perceptual bottleneck. Human Movement Science 7: 225-264.

Bingham, G. P. 1995. Dynamics and the problem of visual event recognition. w: R. Port, T. van Gelder red. Cambridge Mind as Motion: Dynamics, Behavior and Cognition, MA: MIT Press: 403-448.

Bingham, G. P. 2001. "A perceptually driven dynamical model of rhythmic limb movement and bimanual coordination," w: J. D. Moore K. Stenning. red. Proceedings of the 23rd Annual Conference of the Cognitive Science Society Mahwah, NJ: Lawrence Erlbaum Associates, Inc: 75-79.

Bingham, G. P. 2004a. A perceptually driven dynamical model of bimanual rhythmic movement (and phase perception). Ecological Psychology 16: 4553.

Bingham, G. P. 2004b. Another timing variable composed of state variables: phase perception and phase driven oscillators. w: H. Hecht, G. J. P. Savelsbergh red. Advances in Psychology 135: Time-to-Contact, Amsterdam: Elsevier: 421-442.

Brooks, R. A. 1999. Cambrian Intelligence: The Early History of the New AI. Cambridge, MA: MIT Press.

Chapman, S. 1968. Catching a baseball. American Journal of Physiology 36: 868-870.

Chemero, A. 2009. Radical Embodied Cognitive Science. Cambridge, MA: MIT Press.

Chomsky, N. 1959. Verbal behavior. Language 35: 26-58.

Clark, A. 1999. An embodied cognitive science? Trends in Cognitive Science. 3: 345-351.

Clark, A. i Toribio, J. 1994. Doing without representing? Synthese 101: 401-431.

Collins, S., Ruina, A., Tedrake, R. i Wisse, M. 2005. Efficient bipedal robots based on passive dynamic walkers. Science 307: 1082-1085.

Cummins, F. 2012. Oscillators and syllables: a cautionary note. Front. Psychology 3:364. doi:10.3389/fpsyg.2012.00364

Cutting, J. E., i Vishton, P. M. 1995. Perceiving layout and knowing distances: the integration, relative potency, and contextual use of different information about depth. w: W. Epstien, S. Rogers. red. Handbook of Perception and Cognition: Perception of Space and Motion. CA: Academic Press: 69-117. 
Damon W., Lerner, R. M., Kuhn, D. i Siegler, R. S. 2006. Handbook of Child Psychology, Cognition, Perception, and Language. Hoboken: John Wiley \& Sons.

Diamond, A. 2001. Looking closely at infants' performance and experimental procedures in the A-not-B task. Behavioral and brain sciences. 24, 38-41.

Dietrich, E. i Markman, A. B. 2003. Discrete thoughts: why cognition must use discrete representations. Mind and Language 18, 95-119.

Eerland, A., Guadalupe, T., i Zwaan, R. 2011. Leaning to the left makes the Eiffel Tower seem smaller: posture-modulated estimation. Psychological Science 22: 1511-1514.

Fajen, B. R., i Warren, W. H. 2003. Behavioural dynamics of steering, obstacle avoidance and route selection. Journal of Experimental Psychology General Human Perception and Performance 29: 343-362.

Fink, P., Foo, P., i Warren, W. H. 2009. Catching fly balls in virtual reality: a critical test of the outfielder problem. Journal of Vision 9: 1-8.

Fodor, J. 1975. The Language of Thought. Boston: Harvard University Press.

Fodor, J. 2008. LOT 2: The Language of Thought Revisited. Oxford: Oxford University Press.

Georgopoulos, A. P. 1995. Motor cortex and cognitive processing. w: M. S. Gazzaniga red. The Cognitive Neurosciences, Cambridge, MA: MIT Press: 507517.

Gibson, J. J. 1966. The Senses Considered as Perceptual Systems. Boston: Houghton Mifflin.

Gibson, J. J. 1979. The Ecological Approach to Visual Perception. Boston: Houghton Mifflin.

Giraud, A., i Poeppel, D. 2012. Cortical oscillations and speech processing: emerging computational principles and operations. Nature Neuroscience 15: 511-517.

Glenberg, A. M., i Kaschak, M. P. 2002. Grounding language in action. Psychonomic Bulletin Review 9: 558-565.

Golonka, S., i Wilson, A. D. 2012. Gibson's ecological approach - a model for the benefits of a theory driven psychology. Avant 3: 40-53.

Hamilton, W. D. 1971. Geometry for the selfish herd. Journal of theoretical Biology. 31: 295-311.

Hedwig, B., i Webb, B. 2005. Mechanisms underlying phonotactic steering in the cricket, Gryllus bimaculatus, revealed with a fast trackball system. J. Exp. Biol. 208, 915-927. 
Heil, K. H. 1936. Beitrage zur physiologie und psychologie der Springspinnen. Journal of Comparative Physiology A: Neuroethology, Sensory, Neural, and Behavioral Physiology 23, 125-149.

Hund, A. M., i Spencer, J. P. 2003. Developmental changes in the relative weighting of geometric and experience-dependent location cues. Journal of Cognitive Development 4: 3-38.

Kay, B. A., Kelso, J. A. S., Saltzman, E. L., i Schöner, G. 1987. Space-time behavior of single and bimanual rhythmical movements: data and limit cycle model. Journal of Experimental Psychology General Human Perception and Performance 13: 178-192.

Kay, B. A., Saltzman, E. L., i Kelso, J. A. S. 1991. Steady-state and perturbed rhythmical movements: a dynamical analysis. Journal of Experimental Psychology General Human Perception and Performance 17: 183-197.

Kennedy, J. S. 1992. The New Anthropomorphism. Cambridge: Cambridge University Press.

King, A. J., Wilson, A. M., Wilshin i in. 2012. Selfish-herd behaviour of sheep under threat. Current Biology 22: R561-R562.

Lakoff, G. J., i Johnson, M. 1980. Metaphors We Live By. Chicago: University of Chicago.

Lakoff, G. J., i Johnson, M. 1999. Philosophy in the Flesh: The Embodied Mind and Its Challenge to Western Thought. New York, NY: Basic Books.

Luo, H., i Poeppel, D. 2007. Phase patterns of neuronal responses reliably discriminate speech in human auditory cortex. Neuron 54: 1001-1010.

Maris, M., i te Boekhorst, R. 1996. Exploiting physical constraints: heap formation through behavioral error in a group of robots. w: M. Asada. red. Proceedings of IROS '96: IEEE/RSJ International Conference on Intelligent Robots and Systems, Piscataway, NJ: IEEE Press: 1655-1660.

Marr, D. 1982. Vision: A Computational Investigation into the Human Representation and Processing of Visual Information. New York, NY: Henry Holt and Co., Inc

McBeath, M. K., Shaffer, D. M., i Kaiser, M. K. 1995. How baseball outfielders determine where to run to catch fly balls. Science 268: 569-573.

McGeer, T. 1990. Passive dynamic walking. The international journal of robotics research 9: 62-82.

Miles, L., Nind, L., i Macrae, C. 2010. Moving through time. Psychological Science 21: 222-223. 
Montagne, G., Laurent, M., Durey, A., i Bootsma, R. 1999. Movement reversals in ball catching. Experiental Brain Research 129: 87-92.

Muro, C., Escobedo, R., Spector, L., i Coppinger, R. P. 2011. Wolf-pack (Canis lupis) hunting strategies emerge from simple rules in computational simulations. Behavioural processes 88: 192-197.

Peelle, J. E., i Davis, M. H. 2012. Neural oscillations carry speech rhythm through to comprehension. Frontiers in Language Sciences 3:320. doi:10.3389/fpsyg.2012.00320

Pfeifer, R., and Bongard, J. 2007. How the Body Shapes the Way We Think. Cambridge, MA: MIT Press.

Pfeifer, R., i Scheier, C. 1999. Understanding Intelligence. Cambridge, MA: MIT Press.

Piaget, J. 1954. The Construction of Reality in the Child. New York, NY: Basic Books

Port, R. 2007. How are words stored in memory? Beyond phones and phonemes. New Ideas in Psychology 25: 143-170.

Port, R., i Leary, A. 2005. Against formal phonology. Language 81: 927-964.

Raibert, M. H. 1986. Legged Robots That Balance. Cambridge, MA: MIT Press.

Restle, F. 1970. Speed of adding and comparing numbers. Journal of Experimental Psychology 83(Pt 1): 274-278.

Reynolds, C. W. 1987. Flocks, herds, and schools: a distributed behavioral model. ACM SIGGRAPH Computer Graphics 21: 25-34.

Rock, I. 1985. The Logic of Perception. Cambridge, MA: MIT Press.

Runeson, S. 1977. On the possibility of "smart" perceptual mechanisms. Scandinavian Journal of Psychology 18: 172-179.

Runeson, S., i Frykholm, G. 1983. Kinematic specification of dynamics as an informational basis for person and action perception: expectation, gender recognition, and deceptive intention. Journal of Experimental Psychology General 112: 617-632.

Saxberg, B. V. H. 1987a. Projected free fall trajectories. I. Theory and simulation. Biological Cybernetics. 56: 159-175

Saxberg, B. V. H. 1987b. Projected free fall trajectories. II. Human experiments. Biological Cybernetics 56: 177-184.

Schöner, G., i Thelen, E. 2006. Using dynamic field theory to rethink infant habituation. Psychological Review 113: 273-299. 
Shaffer, D. M., i McBeath, M. K. 2005. Naive beliefs in baseball: systematic distortions in perceived time of apex for fly balls. Journal of Experimental Psychology Learning Memory and Cognition 31: 1492-1501.

Shapiro, L. 2011. Embodied Cognition. New York: Routledge Press.

Skinner, B. F. 1957. Verbal Behavior. New York: Appleton-Century-Crofts

Smith, L. B., i Gasser, M. 2005. The development of embodied cognition: six lessons from babies. Artificial Life 11: 13-30.

Smith, L. B., Thelen, E., Titzer, R., i McLin, D. 1999. Knowing in the context of action: the task dynamics of the A-not-B error. Psychological Review 106: 235-260.

Spencer, J. P., i Hund, A. M. 2002. Prototypes and particulars: geometric and experience-dependent spatial categories. Journal of Experimental Psychology General 131: 16-37.

Spencer, J. P., Smith, L. B., i Thelen, E. 2001. Tests of a dynamic systems account of the A-not-B error: the influence of prior experience on the spatial memory abilities of two-year-olds. Child development 72: 1327-1346.

Stanfield, R. A., i Zwaan, R. A. 2001. The effect of implied orientation derived from verbal context on picture recognition. Psychological Science 12: 153156.

Tarsitano, M. S., i Andrew, R. 1999. Scanning and route selection in the jumping spider, Portia labiata. Animal Behavior 58: 255-265.

Tarsitano, M. S., i Jackson, R. R. 1997. Araneophagic jumping spiders discriminate between detour routes that do and do not lead to prey. Animal Behaviour. 53, 257-266.

Thelen, E., Schöner, G., Scheier, C., i Smith, L. B. 2001. The dynamics of embodiment: a field theory of infant perseverative reaching.Behavioral and brain sciences. 24, 1-86.

Turvey, M. T., Shaw, R. E., Reed, E. S., i Mace, W. M. 1981. Ecological laws of perceiving and acting: in reply to Fodor and Pylyshyn (1981). Cognition 9: 237-304.

van Gelder, T. 1995. What might cognition be, if not computation. Journal of Philosophy 92: 345-381.

Webb, B. 1995. Using robots to model animals: a cricket test. Robotics and Autonomous Systems. 16: 117-134.

Webb, B. 1996. A cricket robot. Scientific American 275: 94-99.

Willems, R. M., and Francken, J. C. 2012. Embodied cognition: taking the next step. Front. Psychol. 3:582. doi:10.3389/fpsyg.2012.00582 
Jackson, R. , i Wilcox S. 2002. Jumping Spider Tricksters: Deceit, Predation, and Cognition. M. Bekoff, C. Allen, G. M. Burghardt red. The Cognitive Animal: Empirical and Theorethical Perspectives on Animal Cognition. Cambridge, MA: MIT Press: 27-34.

Wilson, A. D., and Bingham, G. P. 2008. Identifying the information for the visual perception of relative phase. Perception and Psychophysics 70, 465476.

Wilson, M. 2002. Six views of embodied cognition. Psychonomic Bulletin Review 9: 625-636.

Zhu, Q., i Bingham, G. P. 2008. Is hefting to perceive affordances for throwing is a smart perceptual mechanism? Journal of Experimental Psychology General Human Perception and Performance. 34: 929-943.

Zhu, Q., i Bingham, G. P. 2010. Learning to perceive the affordance for longdistance throwing: smart mechanism or function learning? Journal of EXperimental Psychology General Human Perception and Performance 36: 862875.

\begin{abstract}
The most exciting hypothesis in cognitive science right now is the theory that cognition is embodied. Like all good ideas in cognitive science, however, embodiment immediately came to mean six different things. The most common definitions involve the straight-forward claim that "states of the body modify states of the mind." However, the implications of embodiment are actually much more radical than this. If cognition can span the brain, body, and the environment, then the "states of mind" of disembodied cognitive science won't exist to be modified. Cognition will instead be an extended system assembled from a broad array of resources. Taking embodiment seriously therefore requires both new methods and theory. Here we outline four key steps that research programs should follow in order to fully engage with the implications of embodiment. The first step is to conduct a task analysis, which characterizes from a first person perspective the specific task that a perceiving-acting cognitive agent is faced with. The second step is to identify the task-relevant resources the agent has access to in order to solve the task. These resources can span brain, body, and environment. The third step is to identify how the agent can assemble these resources into a system capable of solving the problem at hand. The last step is to test the agent's performance to confirm that agent is actually using the solution identified in step 3. We explore these steps in more detail with reference to two useful examples (the outfielder problem and the A-not-B error), and introduce how to apply this analysis to the thorny question of language use. Embodied cognition is more than we think it is, and we have the tools we need to realize its full potential.
\end{abstract}

Keywords: embodied cognition, dynamical systems, replacement hypothesis, robotics, outfielder problem,A-not-B error, language. 